\title{
ipen
}

AUTARQUIA ASSOCIADA À UNIVERSIDADE DE SÃO PAULO

\section{ESTUDO DA ELETRO-OXIDAÇÃO DA MISTURA H2/CO UTILIZANDO ELETROCATALISADORES À BASE DE Pt/C E CÉRIA DOPADA COM ÍTRIA OU RUTÊNIO PARA APLICAÇÃO EM CÉLULAS A COMBUSTÍVEL DE MEMBRANA POLIMÉRICA CONDUTORA DE PRÓTONS}

Ligia Cristina D'Aloia Lulio

\author{
Dissertação apresentada como parte \\ dos requisitos para obtenção do Grau \\ de Mestre em Ciências na Área \\ de Tecnologia Nuclear - Materiais \\ Orientador: \\ Prof. Dr. Marcelo Linardi
}


INSTITUTO DE PESQUISAS ENERGÉTICAS E NUCLEARES

Autarquia associada à Universidade de São Paulo

\section{ESTUDO DA ELETRO-OXIDAÇÃO DA MISTURA $\mathrm{H}_{2} / \mathrm{CO}$ UTILIZANDO ELETROCATALISADORES À BASE DE Pt/C E CÉRIA DOPADA COM ÍTRIA OU RUTÊNIO PARA APLICAÇÃO EM CÉLULAS A COMBUSTÍVEL DE MEMBRANA POLIMÉRICA CONDUTORA DE PRÓTONS}

LIGIA CRISTINA D’ ALOIA LULIO

Dissertação apresentada como parte dos requisitos para obtenção do Grau de Mestre em Ciências na Área de Tecnologia Nuclear - Materiais.

Orientador:

Prof. Dr. Marcelo Linardi

SÃO PAULO

2012 


\section{DEDICATÓRIA}

Dedico este trabalho aos meus pais, Gilberto Mario Lulio e Izildinha Maria D' Aloia Lulio, que sempre acreditaram e me mostraram que o conhecimento é algo que é somente nosso, o único bem que realmente temos e que ninguém pode nos tirar. Dedico este trabalho à todos os D'Aloia"S" e Lulio"S", que existiram, existem e os que ainda virão. 


\section{AGRADECIMENTOS}

Agradeço o Prof. Dr. Marcelo Linardi, que foi meu orientador neste trabalho. Agradeço também a Prof. Dra. Eliana M. Aricó, que se dedicou a este trabalho como co-orientadora.

Ao prof. Almir de Oliveira Neto, pela ajuda no desenvolvimento e conclusão deste trabalho.

Aos professores Dr. Estevam Vitorio Spinacè e Dra. Elisabete Inácio Santiago, sempre dispostos a ajudar.

Agradecimentos especiais, à pessoas especiais que conheci no laboratório do Centro de Células a Combustível e Hidrogênio $(\mathrm{CCCH})$, que me ajudaram e me aturaram durante este percurso. São elas:

Roberta Alvarenga Isidoro, que interpreta curvas de polarização e notas musicais;

Mauro André Dresch, a pessoa mais doce do laboratório;

Julio Nandenha, que atravessou o mar em busca de um sonho, e que hoje nos presenteia a cada dia com sua presença, seu sorriso e seu enorme coração;

Gustavo Doubek, pesquisador e fotógrafo favorito;

E também, Shayenne Nóbrega, sempre alegre e engraçada; a mineirinha Sirlane Gomes; o famoso Ricardinho R. Dias; o amigo Rafael Nogueira Bonifácio; a falante Rita Maria Dutra ; o reclamão mais querido Rudy Crisafulli; Zakarya Ahmed com sua xícara de café; o prof. de francês Henrique P. Ferreira; a tenente Natália K. Monteiro; a sorridente Vilmária; ao atrapalhado Bruno Ribeiro de Matos.

Aos meus "irmãos de arma", os Tenentes Andreia Goulart Travaglia, Maria Martins Mennucci, Natyara Lopes de Oliveira Barbosa Fachini, Amanda Abati Aguiar, Clarissa Danielle Mendonça de Oliveira, Leonardo de Carvalho Pinheiro, 
Ruy Carvalho Mattosinho de Castro Ferraz, Francisco Carlos Salles de Souza, Victor Ishizuca Teles, Juliano Carlos de Oliveira, Amauri Silva Costa, Walter Dawid Retzer, Thiago Zuccon e Silva, Fellipe Garcia Marques, Fabiana Costa de Oliveira, Catiano Cristian de Luca, Marcos Alexandre de Vasconcelos Cavalcanti, Márcia Ferraresi de Araujo, David Julio da Costa, João Henrique Gulineli Fachini, Giliard José arruda, Neilton Barbosa de Asis, Paulo Vinicius Franchin, Thiago Calil Mendes de Paula, Júlio César dos Santos Alves, Lucio Agostinho de Oliveira e Elielton Bezerra Pupo.

Ao Instituto de Pesquisas Energéticas e Nucleares (IPEN).

Ao Conselho Nacional de Desenvolvimento Científico e Tecnológico (CNPq).

Ao Centro Tecnológico da Marinha em São Paulo (CTMSP).

A todos meus amigos e familiares, pela ajuda, força e compreensão. 
"Nenhum homem realmente produtivo pensa como se estivesse escrevendo uma dissertação." 


\title{
ESTUDO DA ELETRO-OXIDAÇÃO DA MISTURA $\mathrm{H}_{2}$ /CO UTILIZANDO OS ELETROCATALISADORES A BASE DE Pt/C E CÉRIA DOPADA COM ÍTRIA OU RUTÊNIO PARA APLICAÇÃO EM CÉLULAS A COMBUSTÍVEL DE MEMBRANA POLIMÉRICA CONDUTORA DE PRÓTONS
}

\author{
Ligia Cristina D’Aloia Lulio
}

\section{RESUMO}

As formulações de eletrocatalisadores Pt: $\left(\mathrm{Ce}_{0,9} \mathrm{Y}_{0,1} \mathrm{O}_{2}\right)+\mathrm{Pt} / \mathrm{C}$ Etek, Pt: $\left(\mathrm{Ce}_{0,9} \mathrm{Ru}_{0,1} \mathrm{O}_{2}\right)+\mathrm{Pt} / \mathrm{C}$ Etek, Pt:Ce $\mathrm{C}_{0,9} \mathrm{Y}_{0,1} \mathrm{O}_{2} / \mathrm{C}$ e $\mathrm{Pt}: \mathrm{Ce}_{0,9} \mathrm{Ru}_{0,1} \mathrm{O}_{2}+\mathrm{RuO}_{2} / \mathrm{C}$ foram preparados pelo método da redução por álcool e caracterizados por difração de raios $X(D R X)$ e microscopia eletrônica de transmissão (MET). A tolerância ao CO foi estudada utilizando o stripping de $\mathrm{CO}$ e medidas de curvas de polarização em células unitárias alimentadas com misturas de $\mathrm{H}_{2} / \mathrm{CO}$ no ânodo e oxigênio no cátodo, na temperatura de $80^{\circ} \mathrm{C}$ e pressão absoluta de 2 bar para ânodo e cátodo. Os testes em células a combustível tipo PEMFC mostraram que a oxidação do $\mathrm{CO}$ adsorvido a $\mathrm{CO}_{2}$ na superfície da platina ocorre em potenciais menos positivos quando comparado com o catalisador comercial, Pt/C Etek, mostrando tolerância ao $\mathrm{CO}$ adsorvido nos eletrocatalisadores de Pt:Ce $e_{0,9} \mathrm{Y}_{0,1} \mathrm{O}_{2} / \mathrm{C}$ e Pt: $\left(\mathrm{Ce}_{0,9} \mathrm{Ru}_{0,1} \mathrm{O}_{2}+\mathrm{RuO}_{2}\right) / \mathrm{C}$.

Palavras chave: PEMFC, $\mathrm{H}_{2} / \mathrm{CO}, \mathrm{CeO}_{2}$ 


\title{
STUDY OF ELECTRO-OXIDATION THE MIX $\mathrm{H}_{2} / \mathrm{CO}$ USING Pt/C Etek AND YTTRIA OR RUTHENIUM DOPED CERIA ELECTROCATALYSTS FOR PROTON EXCHANGE MEMBRANE FUEL CELL
}

\author{
Ligia Cristina D’Aloia Lulio
}

\begin{abstract}
Pt: $\left(\mathrm{Ce}_{0,9} \mathrm{Y}_{0,1} \mathrm{O}_{2}\right)+\mathrm{Pt} / \mathrm{C} \quad$ Etek, Pt: $\left(\mathrm{Ce}_{0,9} \mathrm{Ru}_{0,1} \mathrm{O}_{2}\right)+\mathrm{Pt} / \mathrm{C} \quad$ Etek, $\mathrm{Pt}: \mathrm{Ce}_{0,9} \mathrm{Y}_{0,1} \mathrm{O}_{2} / \mathrm{C}$ e Pt:Ce $e_{0,9} \mathrm{Ru}_{0,1} \mathrm{O}_{2}+\mathrm{RuO}_{2} / \mathrm{C}$ electrocatalysts, were prepared by an alcohol reduction process. The electrocatalysts were characterized by X-Ray Difratometry (XRD) end Transmission Electronic Microscopy (TEM). the CO tolerance was studied using $\mathrm{CO}$ stripping and measurements of polarization curves single-cell fed with $\mathrm{H}_{2} / \mathrm{CO}$ mixture at the anode and oxygen at the cathode, at a temperature of $85^{\circ} \mathrm{C}$ and absolute pressure of 2 bar for anode and cathode. The results showed that the oxidation of $\mathrm{CO}$ adsorbed to $\mathrm{CO} 2$ on the surface of platinum occur at less positive potentials compared to $\mathrm{Pt} / \mathrm{C}$ Etek showing the tolerance to $\mathrm{CO}$ adsorbed on these Pt:Ce $\mathrm{C}_{0,9} \mathrm{Y}_{0,1} \mathrm{O}_{2} / \mathrm{C}$ e Pt: $\left(\mathrm{Ce}_{0,9} \mathrm{Ru}_{0,1} \mathrm{O}_{2}+\mathrm{RuO}_{2}\right) / \mathrm{C}$ electrocatalysts.
\end{abstract}

Key words: PEMFC, $\mathrm{H}_{2} / \mathrm{CO}, \mathrm{CeO}_{2}$ 


\section{SUMÁRIO}

\section{Página}

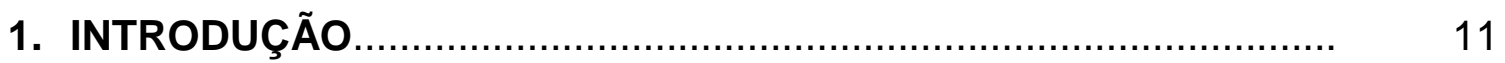

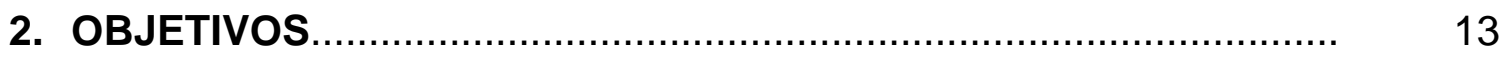

3. REVISÃO DA LITERATURA......................................................

3.1. CÉLULAS A COMBUSTÍVEL....................................................... 14

3.1.1. Célula com Membrana Polimérica Trocadora de Prótons (PEMFC) ...........................................................................

3.2. MONÓXIDO DE CARBONO........................................................ 18

3.3. ELETROCATALISADORES ...................................................... 21

3.4. RUTÊNIO............................................................................ 22

3.5. TERRAS RARAS.................................................................. 23

3.5.1. Óxido de Cério (IV)............................................................... 23

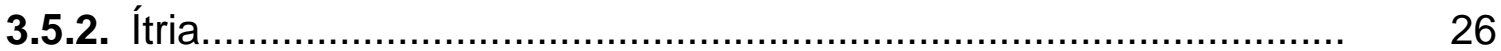

3.6. DOPAGEM DA CÉRIA ............................................................. 26

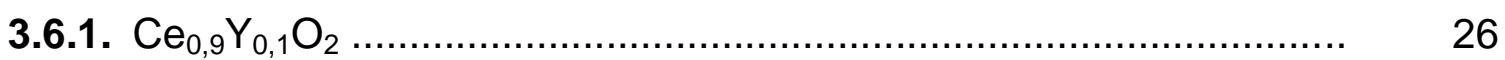

4. METODOLOGIA EXPERIMENTAL ............................................ 29

4.1. PREPARAÇÃO DOS ELETROCATALISADORES.......................... 29

4.1.1. Preparação dos eletrocatalisadores $P t: \mathrm{Ce}_{0,9} \mathrm{Y}_{0,1} \mathrm{O}_{2}+\mathrm{Pt}$ E-tek e Pt: $\left(\mathrm{Ce}_{0,9} \mathrm{Ru}_{0,1} \mathrm{O}_{2}+\mathrm{RuO}_{2}\right)+$ Pt E-tek.............................................. 29

4.1.2. Preparação dos eletrocatalisadores de $\mathrm{Pt}^{-} \mathrm{Ce}_{0,9} \mathrm{Y}_{0,1} \mathrm{O}_{2} / \mathrm{C}$ e

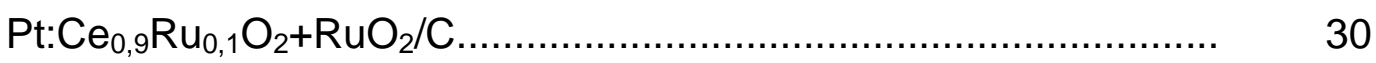

4.2. CARACTERIZAÇÃO DOS ELETROCATALISADORES................... 31

4.2.1. Análise de difração de raio $X(D R X)$............................................... 31

4.2.2. Análise de microscopia eletrônica de transmissão (MET)............... 32

4.3. FABRICAÇÃO DO CONJUNTO ELETRODOS-MEMBRANA

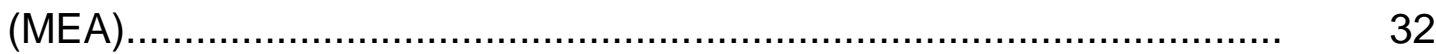

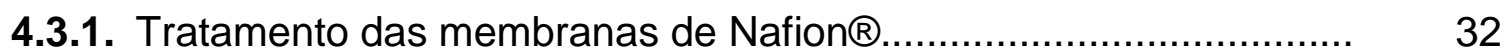




\section{Página}

4.3.2. Camada catalisadora..................................................................

4.3.3. Conjunto eletrodo-membrana-eletrodo (MEA) .............................. 34

4.4. STRIPPING DE CO.............................................................. 36

4.5. MEDIDAS DE POLARIZAÇÃO EM CÉLULA A COMBUSTÍVEL

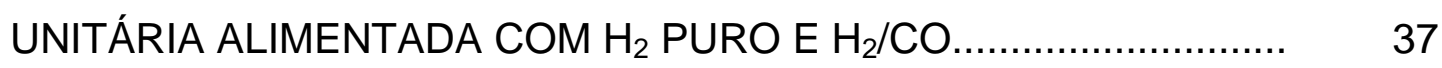

5. RESULTADOS E DISCUSSÕES...................................................... 39

5.1. Eletrocatalisadores DE Pt: $\left(\mathrm{Ce}_{0,9} \mathrm{Y}_{0,1} \mathrm{O}_{2}\right)+\mathrm{Pt} / \mathrm{C}$ Etek $\mathrm{E}$ Pt: $\left(\mathrm{Ce}_{0,9} \mathrm{Ru}_{0,1} \mathrm{O}_{2}+\mathrm{RuO}_{2}\right)+\mathrm{Pt} / \mathrm{C}$ Etek.............................................

5.1.1. Caracterização de eletrocatalisadores $P t: \mathrm{Ce}_{0,9} \mathrm{Y}_{0,1} \mathrm{O}_{2}+\mathrm{Pt} / \mathrm{C}$ Etek $\mathrm{E}$ Pt: $\mathrm{Ce}_{0,9} \mathrm{Ru}_{0,1} \mathrm{O}_{2}+\mathrm{RuO}_{2}+\mathrm{Pt} / \mathrm{C}$ Etek............................................ 38

5.1.2. Avaliação eletroquímica da reação de oxidação de CO................... 43

5.1.2.1. Stripping de CO.................................................................

5.1.2.2. Curva de Polarização........................................................... 45

5.2. ElETROCATALISAdORES DE Pt:Ce $e_{0,9} \mathrm{Y}_{0,1} \mathrm{O}_{2} / \mathrm{C} \quad \mathrm{E}$

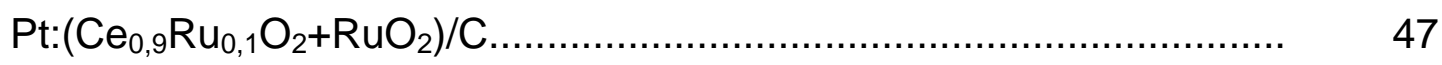

5.2.1. Caracterização de eletrocatalisadores $P t: \mathrm{Ce}_{0,9} \mathrm{Y}_{0,1} \mathrm{O}_{2} / \mathrm{C} \quad \mathrm{E}$

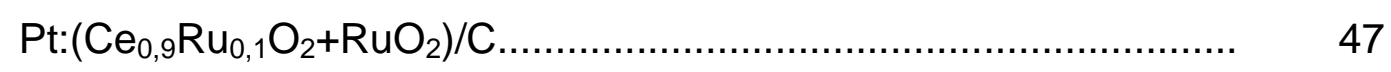

5.2.2. Avaliação eletroquímica da reação de oxidação de CO.................. 53

5.2.2.1. Stripping de CO................................................................ 53

5.2.2.2. Curvas de Polarização........................................................ 55

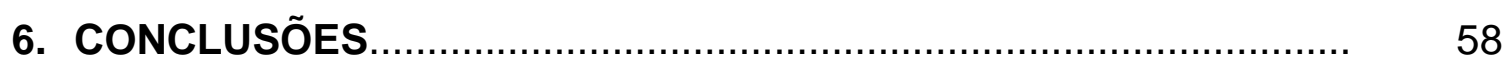

7. REFERÊNCIAS BIBLIOGRÁFICAS ............................................... 60 


\section{INTRODUÇÃO}

Em um período de 150 anos, o mundo desenvolvido transitou de madeira para o carvão, adicionando posteriormente o petróleo, o gás natural e as energias hidrelétricas e nuclear, e mais recentemente as energias renováveis [1]. Preocupações a nível global chamam cada vez mais a atenção da humanidade, tais preocupações são as limitações nas reservas de combustíveis fósseis, a questão ambiental/poluição gerada, o alto consumo e a distribuição de energia, uma legislação cada vez mais exigente e forças sócio-econômicas, que de certo modo, incentivam avanços tecnológicos e a adoção de novos recursos energéticos.

Surge então o hidrogênio como componente chave para um sistema energético limpo e sustentável, iniciando assim, uma nova era para energia. A democratização da energia também surge com esse nova era, sendo que uma das principais vantagens da utilização do hidrogênio como fonte de energia é que ele pode ser obtido através de uma grande gama de recursos energéticos e matérias-primas, possibilitando a cada país ou região utilizar os que mais se adéqüem à sua realidade.

A transição para a economia do hidrogênio acontecerá por etapas, sendo estas marcadas pelos avanços tecnológicos e pela aceitação das novas tecnologias. Os governos farão parte dessas fases, no que diz respeito ao incentivo à investigação e desenvolvimento e também na elaboração de códigos e normas de segurança [1].

Visando uma energia limpa e utilizando o hidrogênio, tem-se a célula a combustível uma forma promissora de geração de energia, já que pode ser uma fonte de energia limpa e ter aplicação sob forma estacionária, móvel e/ou portátil [2].

Quando se trata da oxidação de combustíveis em eletrodos, o hidrogênio é o único que pode ser oxidado sobre platina com uma cinética suficientemente rápida, capaz de produzir elevadas densidades de corrente. 
Entretanto, a geração de hidrogênio de fontes carbonáceas é problemática em relação ao catalisador de platina devido ao seu envenenamento pelo $\mathrm{CO}$, principalmente se a reação eletroquímica se processa em temperaturas baixas 0 que é o caso nas células a combustível PEM, que tem sua temperatura de operação limitada, entre 60 a $80^{\circ} \mathrm{C}$, em função da necessidade da hidratação da membrana condutora de prótons. Em temperaturas tão baixas quanto a de operação das células PEM a atividade do catalisador de platina é prejudicada se a concentração de CO no gás combustível exceder 10 ppm [3]. Este problema está sendo solucionado com o desenvolvimento de catalisadores tolerantes a $\mathrm{CO}$, que consistem em ligas de platina com metais que facilitam a oxidação do CO. Geralmente estes eletrocatalisadores, são binários, ternários ou quaternários; combinações de platina e elementos oxofílicos tais como Ru, Mo, W, etc. [4].

Os elementos adicionais chamados de co-catalisadores promovem a eletro-oxidação de $\mathrm{CO}$ para $\mathrm{CO}_{2}$, através do processo de formação de espécies óxido/hidróxidas formadas sobre os sítios oxofílicos para o CO adsorvido nos sítios da platina, como proposto pelos mecanismos bifuncional e efeito eletrônico [4]. Alguns trabalhos apresentaram estudos sobra a oxidação seletiva de $\mathrm{CO}$ na presença de hidrogênio, utilizando catalisadores que contêm suportes que podem ativar o oxigênio maximizando os benefícios catalíticos a partir das interações entre o oxigênio e o suporte, podendo-se mencionar as misturas de óxidos baseados em céria $\left(\mathrm{Ce}_{x} \mathrm{M}_{1-\mathrm{x}} \mathrm{O}_{y}\right)$, os quais são sólidos versáteis trocadores de oxigênio e candidatos ideais para aplicações eletrocatalíticas e/ou catalíticas em células a combustível [5].

Neste contexto, foram escolhidos neste trabalho o estudo de eletrocatalisadores baseados em céria dopada com ítria e céria dopada com rutênio, para a oxidação direta de um combustível composto de uma mistura de hidrogênio e CO 100 ppm. 


\section{OBJETIVOS}

O objetivo principal deste trabalho consiste no estudo de sistemas com formulação de eletrocatalisadores de Pt: $\left(\mathrm{Ce}_{0,9} \mathrm{Y}_{0,1} \mathrm{O}_{2}\right)+\mathrm{Pt} / \mathrm{C}$ Etek, Pt: $\left(\mathrm{Ce}_{0,9} \mathrm{Ru}_{0,1} \mathrm{O}_{2}\right)+\mathrm{Pt} / \mathrm{C}$ Etek, Pt:Ce $e_{0,9} \mathrm{Y}_{0,1} \mathrm{O}_{2} / \mathrm{C}$ e Pt:Ce $e_{0,9} \mathrm{Ru}_{0,1} \mathrm{O}_{2}+\mathrm{RuO}_{2} / \mathrm{C}$ para ânodos com maior tolerância ao monóxido de carbono (CO), para aplicação em células a combustível do tipo membrana polimérica trocadora de prótons (PEMFC). Caracterização físico-química e avaliação de desempenho por meio de curvas de polarização em estado estacionário em células unitárias. 


\section{REVISÃO DA LITERATURA}

\subsection{Células a Combustível}

As células a combustível são dispositivos eletroquímicos que convertem energia química diretamente em energia elétrica e calor através de uma alimentação externa e constante de combustível (Figura 1). Esta conversão ocorre pela oxidação de um combustível no ânodo e a redução de um oxidante no cátodo [2].

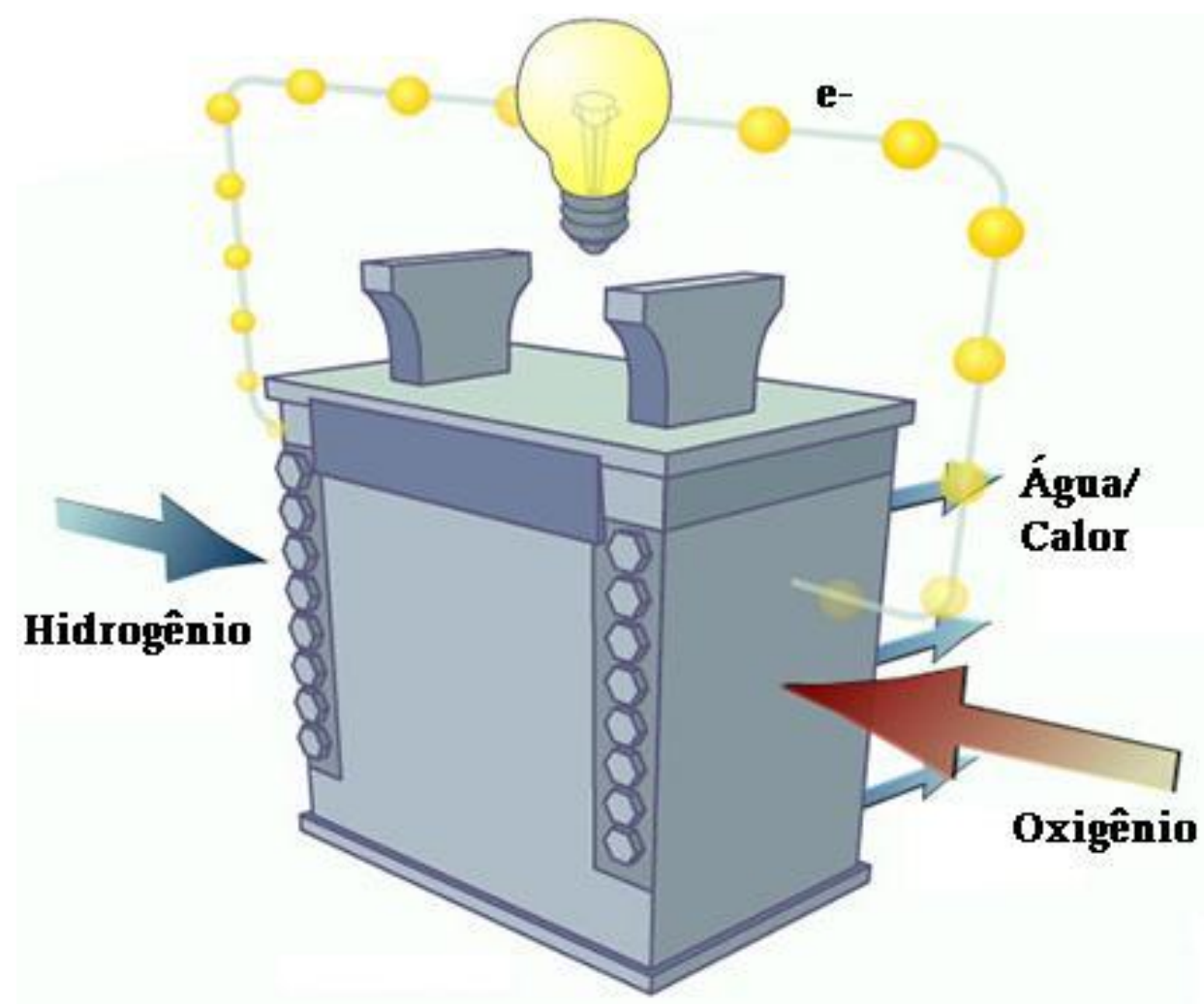

FIGURA 1. Esquema de uma célula a combustível [6].

Como existem vários tipos de células a combustível, elas são classificadas de acordo com sua temperatura de operação, sendo assim, classificam-se em dois grupos, as de alta temperatura e as de baixa. As de alta temperatura de operação são a célula a combustível de carbonato fundido (Molten Carbonate Fuel Cell - MCFC) e a célula a combustível de óxido sólido (Solid 
Oxide Fuel Cell - SOFC). As de baixa temperatura de operação são a célula a combustível alcalina (Alkaline Fuel Cell-AFC), a célula a combustível trocadora de prótons (Proton Exchange Membrane Fuel Cell - PEMFC), a célula a combustível a metanol direto (Direct Methanol Fuel Cell - DMFC) e a célula a combustível de ácido fosfórico (Phosphoric Acid Fuel Cell -PAFC) [2],conforme Figura 2.

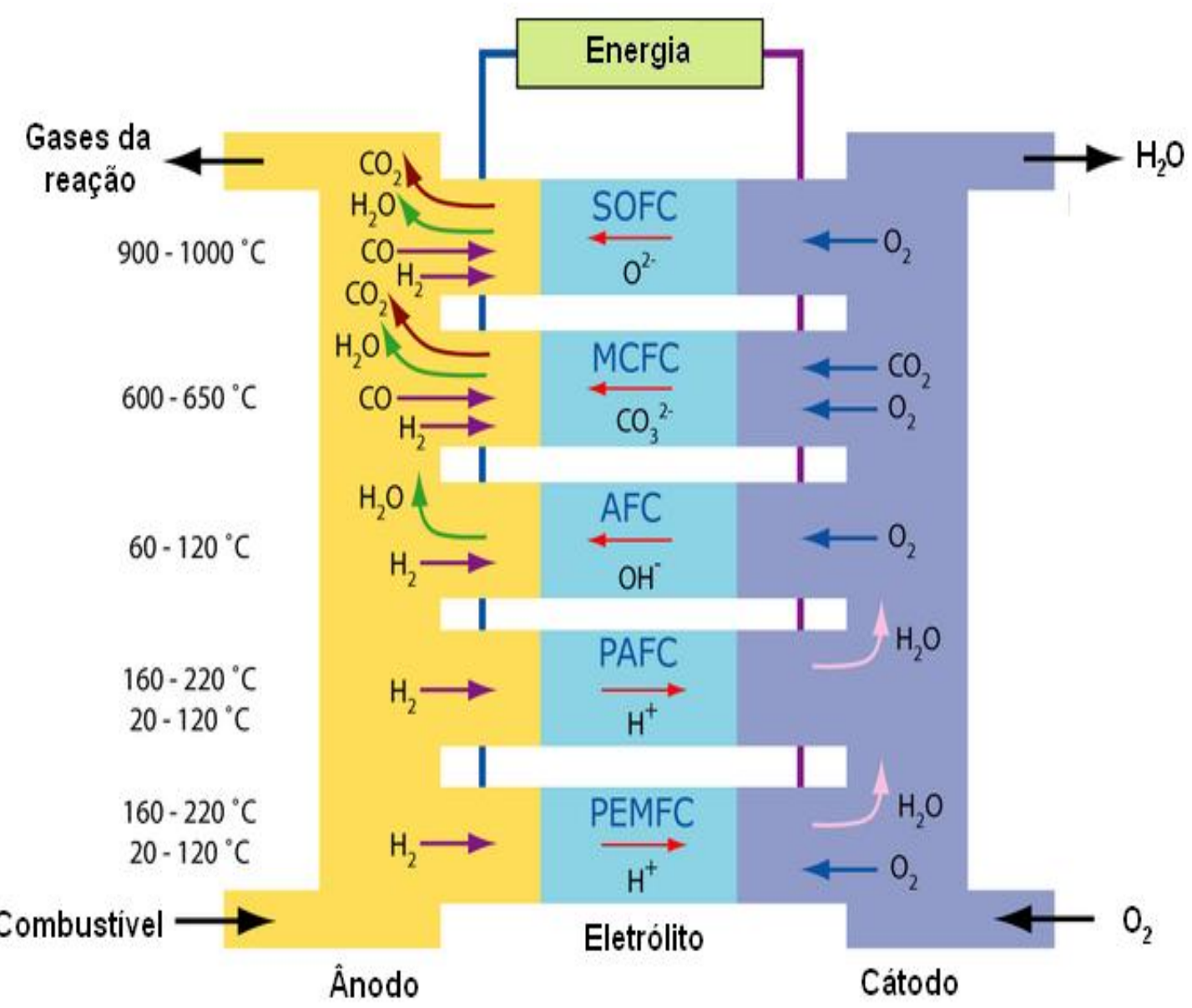

FIGURA 2. Tipos de células a combustível [7].

\subsubsection{Célula com Membrana Polimérica Trocadora de Protons (PEMFC)}

A célula a combustível de membrana trocadora de prótons (PEMFC) é o tipo mais flexível e promissora, já que as aplicações podem ser portáveis, estacionárias e automotivas, apresenta elevada densidade de potência $(1 \mathrm{~kW} / \mathrm{kg})$, baixo peso, simplicidade de operação, alta estabilidade química e baixa temperatura de operação. 
Ela é baseada no uso de uma membrana Nafion $\AA$, que quando umidificada conduz prótons. Quando a PEMFC é alimentada com $\mathrm{H}_{2}$, como combustível, no ânodo e $\mathrm{O}_{2}$, como oxidante, no cátodo, ocorrem as seguintes reações:

$$
\begin{aligned}
& 2 \mathrm{H}_{2(\mathrm{~g})} \rightarrow 4 \mathrm{H}^{+}{ }_{(\mathrm{aq})}+4 \mathrm{e}^{-} \\
& E^{0}=0,0 \mathrm{~V} \text { (vs. NHE) Equação } 1 \\
& \mathrm{O}_{2(\mathrm{~g})}+4 \mathrm{H}^{+}{ }_{(\mathrm{aq})}+4 \mathrm{e}^{-} \rightarrow 2 \mathrm{H}_{2} \mathrm{O}_{(\mathrm{l})} \\
& E^{0}=1,23 \vee \text { (vs. NHE) Equação } 2 \\
& 2 \mathrm{H}_{2(\mathrm{~g})}+\mathrm{O}_{2(\mathrm{~g})} \rightarrow 2 \mathrm{H}_{2} \mathrm{O}_{(\mathrm{l})} \\
& E^{0}=1,23 \vee \text { (vs. NHE) Equação } 3
\end{aligned}
$$

Em uma célula PEM o hidrogênio alimentado no ânodo, se oxida, formando $\mathrm{H}^{+}$e elétrons. Os ions $\mathrm{H}^{+}$migram pela membrana em direção ao cátodo e os elétrons livres atravessam um circuito externo, produzindo energia (Eq. 1). No cátodo, o oxigênio alimentado é reduzido (Eq.2) e se combina com os ions $\mathrm{H}^{+}$ e com os elétrons formando água e calor (Eq. 3), conforme Figura 3.

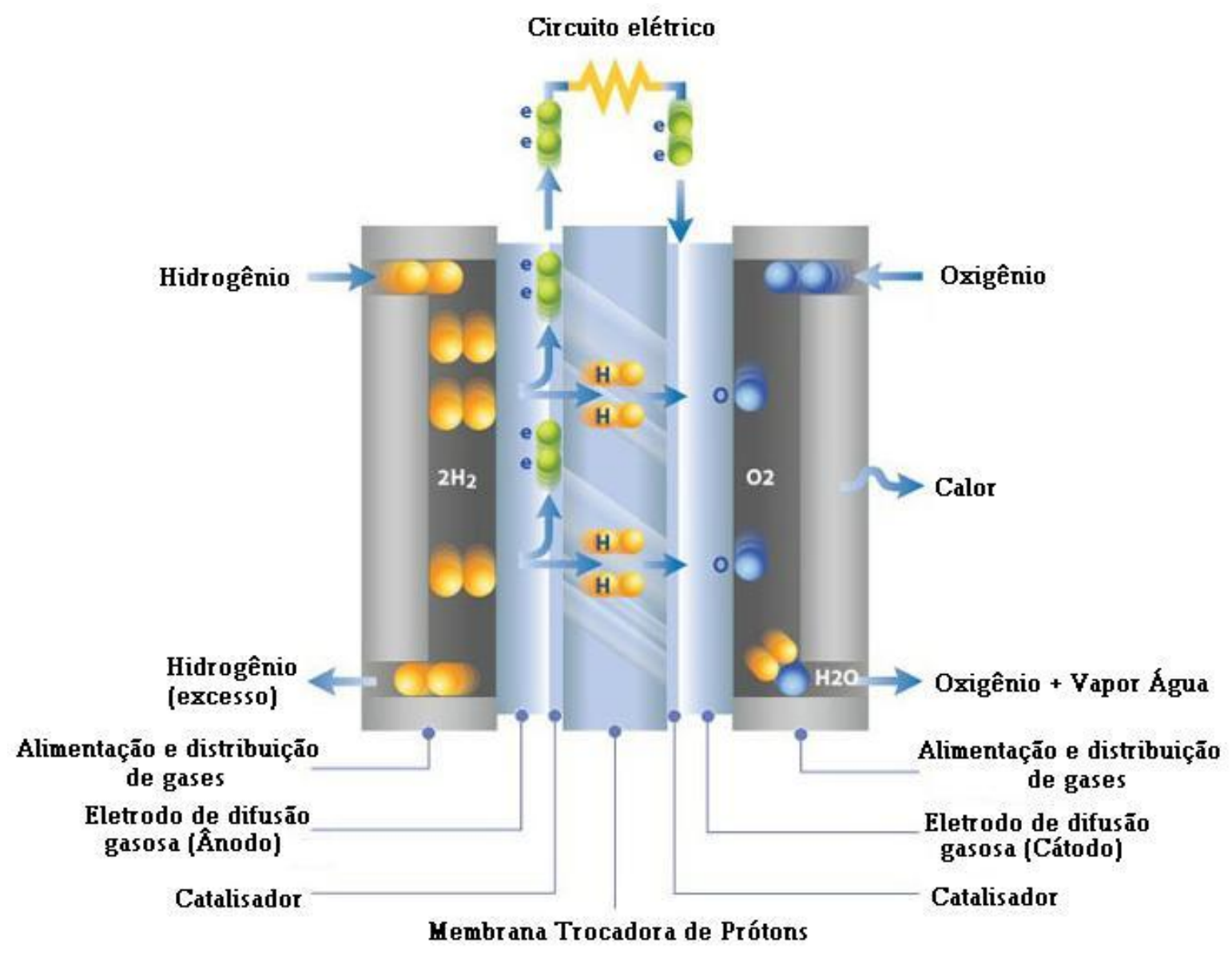

FIGURA 3. Célula a combustível com membrana polimérica trocadora de prótons [8]. 
O oxigênio utilizado com oxidante na célula,pode ser obtido diretamente do ar atmosférico, já para se obter hidrogênio, a forma mais econômica é através do processo de reforma catalítica do metano.

O desempenho de uma célula a combustível geralmente é dado em função de curvas de polarização, ou seja, curvas da dependência do potencial com a densidade de corrente, conforme ilustra na Figura 4. O sobrepotencial é uma medida do quanto o potencial se afasta do potencial de equilíbrio, e em uma célula a combustível, encontram-se presentes pelo menos três sobrepotenciais, sendo eles a polarização por ativação, por queda Ôhmica e por transporte de massa [9].

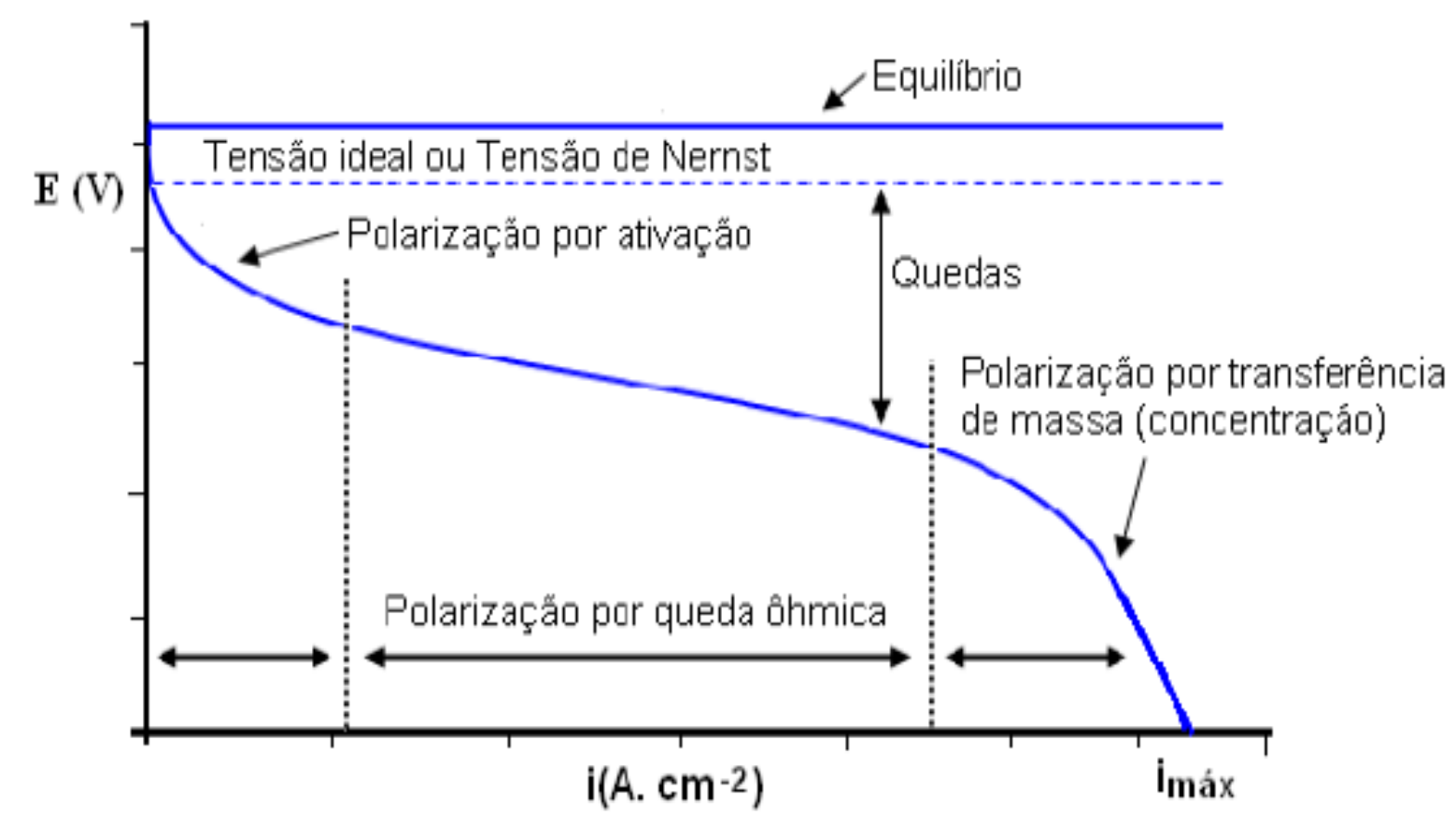

FIGURA 4. Curva de polarização típica de uma célula tipo PEMFC [10].

A polarização por ativação está associada à resistência à transferência de carga na interface do eletrodo, a polarização por queda Ôhmica está relacionada à resistência ôhmica dos componentes da célula e a polarização por transporte de massa está relacionada à difusão das espécies envolvidas na reação até a interface do eletrodo [2]. 


\subsection{Monóxido de Carbono}

O hidrogênio obtido de forma mais econômica, é o proveniente do processo de reforma de hidrocarbonetos (reforma a vapor). O processo de reforma sempre deixa traços de CO no hidrogênio, envenenando os eletrocatalisadores utilizados no ânodo [11-12], fazendo com que o desempenho da célula diminua significativamente [3,12]. Esse envenenamento ocorre na superfície da platina, pois o CO é adsorvido fortemente nos sítios ativos, desfavorecendo a adsorção e a reação de oxidação do $\mathrm{H}_{2}$.

Na Figura 5, é possível verificar uma perda significativa no rendimento da célula através da presença de $\mathrm{CO}$, que age como um "veneno catalítico", ou seja, ocorre uma desativação parcial do catalisador. O potencial termodinâmico da célula para corrente nula é de $1,23 \mathrm{~V}$ (vs. EPH), a $25^{\circ} \mathrm{C}$, porem com a solicitação de carga, ou seja, aumento da corrente, ocorre uma queda de potencial decorrente da reação de redução de oxigênio, pois a velocidade da reação é controlada pela sua cinética. A outra causa de perda de potência, está associada ao aumento de sobrepotencial para a reação anódica, provocado pela presença de $\mathrm{CO}$, onde observa-se que traços de $\mathrm{CO}$ presentes no hidrogênio causam perda de rendimento, quando comparado com o hidrogênio puro [13].

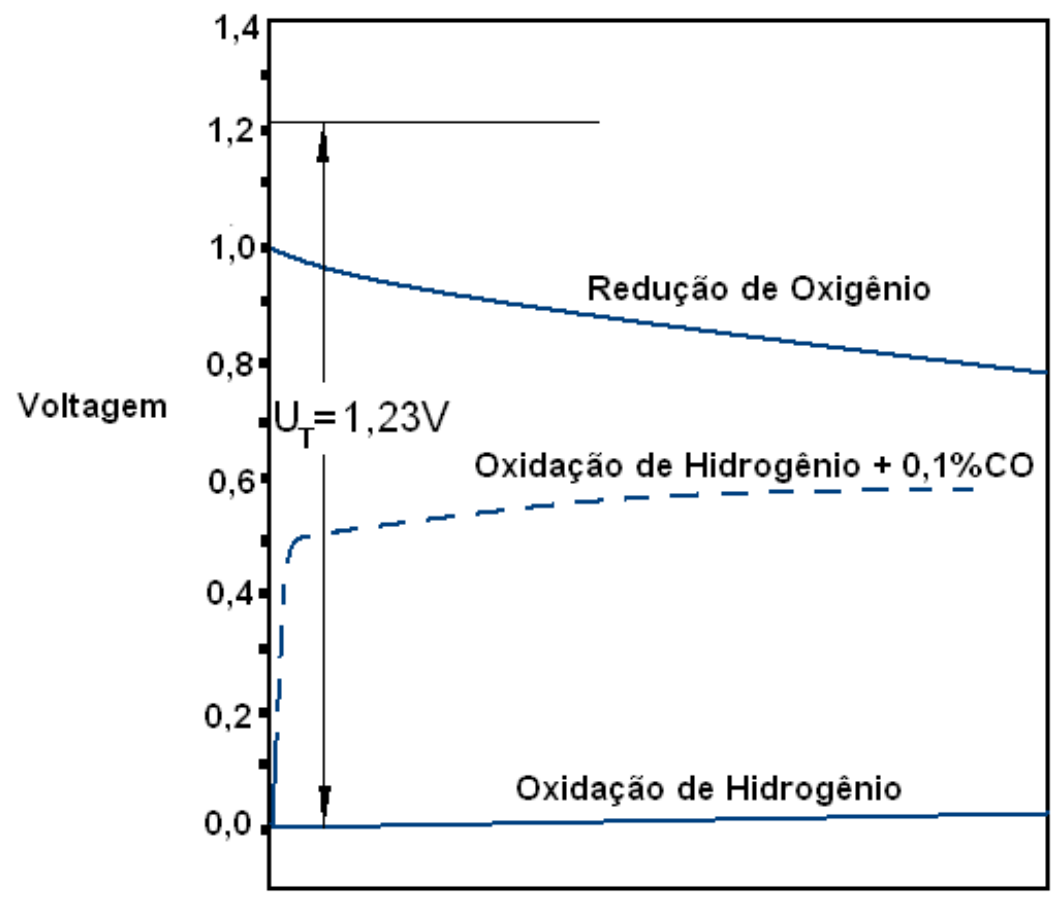

I/A

FIGURA 5. Influência do CO no rendimento da célula. 
O problema do envenenamento do catalisador está sendo parcialmente solucionado com o desenvolvimento de catalisadores tolerantes a $\mathrm{CO}$, que consistem em ligas de platina com metais que facilitam a oxidação do $\mathrm{CO}$. Geralmente estes eletrocatalisadores, são binários, ternários ou quaternários; combinações de platina e elementos oxofílicos tais como Ru, Mo, W, etc [14-16].

As três possibilidades de $\mathrm{CO}$ adsorvido dependem do grau de recobrimento de $\mathrm{CO}$, da estrutura cristalina e do potencial de eletrodo ( $\mathrm{CO}$ linear $\left(\mathrm{CO}_{\mathrm{L}}\right)$, $\mathrm{CO}$ ligado por ponte $\left(\mathrm{CO}_{\mathrm{B}}\right)$ e $\mathrm{CO}$ multiligado $\left.\left(\mathrm{CO}_{M}\right)\right)$. A adsorção de $\mathrm{CO}_{L}$ envolve um sítio de Pt e uma molécula de $\mathrm{CO}$, a adsorção de $\mathrm{CO}_{\mathrm{B}}$ corresponde a adsorção de uma molécula de $\mathrm{CO}$ em dois sítios de $\mathrm{Pt}$ e no $\mathrm{CO}_{\mathrm{M}}$ a adsorção de uma molécula de $\mathrm{CO}$ em mais de dois sítios de $\mathrm{Pt}$, sendo a adsorção $\mathrm{CO}$ majoritária e mais forte e ocorrendo sua oxidação em potenciais mais positivos, e a $\mathrm{CO}_{\mathrm{B}}$, espécies mais fracamente adsorvidas, ocorrendo em potenciais menos positivos [17,18].

A tolerância dos eletrocatalisadores contendo platina tem sido associada a três mecanismos fundamentais, conforme Figura 6. O mecanismo bifuncional, o efeito eletrônico e o mecanismo de oxidação química via redução de deslocamento da reação de água-gás [15,19-21].

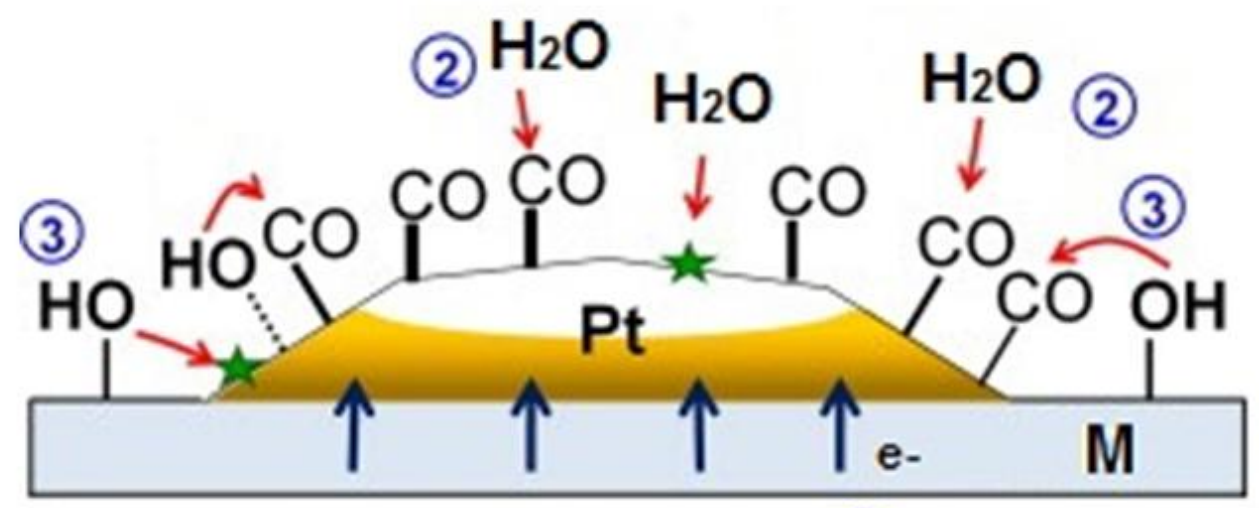

(1)

\section{(1) Efeito eletrônico \\ (2) Mecanismo de oxidação química 3 Mecanismo bifuncional}

FIGURA 6. Mecanismos fundamentais dos eletrocatalisadores contendo platina [22]. 
O mecanismo bifuncional é indicado como o responsável pela maior tolerância de alguns eletrocatalisadores ao $\mathrm{CO}$, apesar de existirem ainda muitos debates sobre o real mecanismo de tolerância [18]. No mecanismo bifuncional o CO é adsorvido na Pt (Eq. 4) e o segundo metal produz espécies oxigenadas ou óxidos hidratados (Eq.5) que oxidam o $\mathrm{CO}$ a $\mathrm{CO}_{2}$ liberando os sítios de platina (Eq.6), conforme reações a seguir:

$$
\begin{array}{ll}
\mathrm{CO}+\mathrm{Pt} \rightarrow \mathrm{Pt}-\mathrm{CO} & \text { Equação 4 } \\
\mathrm{M}+\mathrm{H}_{2} \mathrm{O} \rightarrow \mathrm{M}-\mathrm{OH}+\mathrm{H}^{+}+\mathrm{e}^{-} & \text {Equação } 5 \\
\mathrm{Pt}-\mathrm{CO}+\mathrm{M}-\mathrm{OH} \rightarrow \mathrm{Pt}+\mathrm{M}+\mathrm{CO}_{2}+\mathrm{H}^{+}+\mathrm{e}^{-} & \text {Equação 6 }
\end{array}
$$

A adsorção do $\mathrm{CO}$ na superfície dos metais de transição, baseia-se na transferência de elétrons do orbital $5 \sigma$ do CO para a banda d desocupada ou parcialmente ocupada do metal (Figura 7), bem como no efeito de retro-doação de elétrons do metal aos orbitais $2 \pi$ do $\mathrm{CO}$ [12], conforme Figura 8.

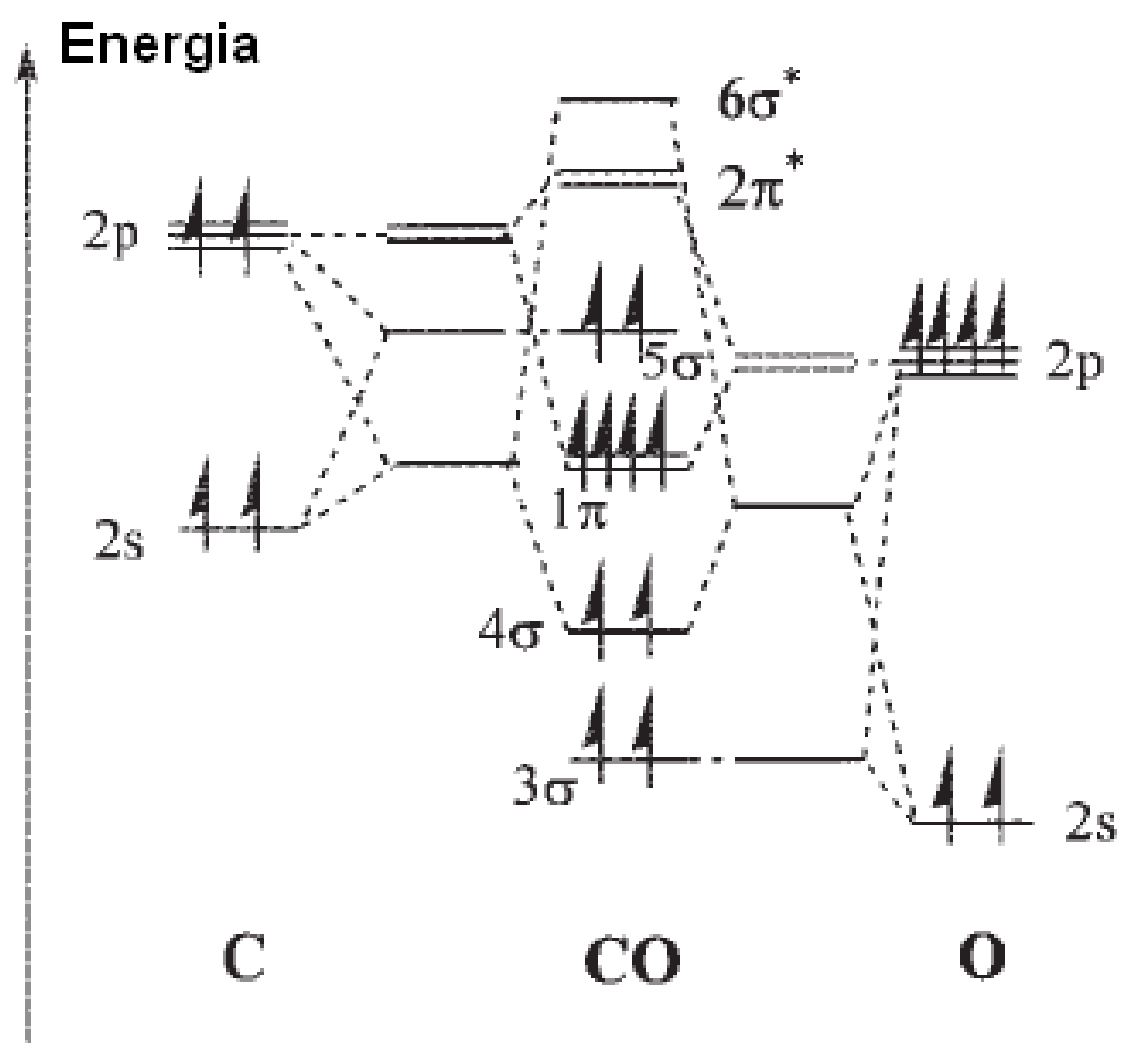

FIGURA 7. Níveis de energia da molécula de CO [24]. 


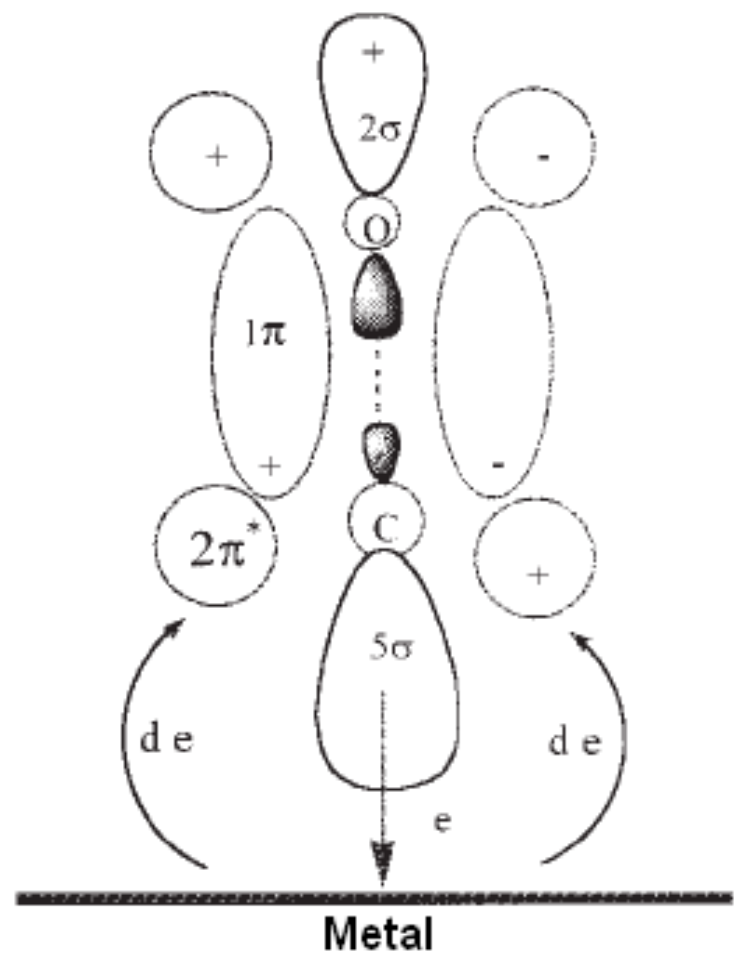

FIGURA 8. Efeito de retro-doação de elétrons do metal aos orbitais $2 \pi$ do $\mathrm{CO}$ [24].

Alguns trabalhos apresentaram estudos sobre a oxidação seletiva de CO na presença de hidrogênio, utilizando catalisadores que contêm suportes que podem ativar o oxigênio maximizando os benefícios catalíticos a partir das interações entre o oxigênio e o suporte $\left(\mathrm{PtRu}-\mathrm{H}_{\mathrm{x}} \mathrm{MeO}_{3} / \mathrm{C}\right.$ e $\mathrm{Ce}_{x} \mathrm{M}_{1-\mathrm{x}} \mathrm{O}_{\mathrm{y}}$, por exemplo) [5,25]. Entre estes catalisadores podem se mencionar as misturas de óxidos baseados em céria $\left(\mathrm{Ce}_{x} \mathrm{M}_{1-\mathrm{x}} \mathrm{O}_{\mathrm{y}}\right)$, os quais são sólidos versáteis trocadores de oxigênio e candidatos ideais para aplicações eletrocatalíticas e/ou catalíticas em células a combustível [25].

\subsection{Eletrocatalisadores}

Existem diferentes metodologias na literatura para preparação de nanopartículas metálicas suportadas em carbono, como eletrocatalisadores, sendo elas o Método do Ácido Fórmico [26], Método de Bönnemann [27], Método da Deposição Espontânea [28], Decomposição de Precursores Moleculares [29] e Método da Redução por Álcool [30]. A metodologia escolhida para realização 
deste trabalho é o método da redução por álcool desenvolvido no Instituto de Pesquisas Energéticas e Nucleares (IPEN) [31], já que é um procedimento de preparação simples e reprodutível. Um trabalho utilizando como eletrocatalisador $\mathrm{PtSn} / \mathrm{CeO}_{2}-\mathrm{C}$ preparado pelo método da redução por álcool para a oxidação eletroquímica do etanol mostrou que quando utilizado proporções de $\mathrm{CeO}_{2}$ de $15 \%$ em massa, atinge um melhor desempenho da célula do que utilizando somente PtSn-C, este resultado atesta o uso da Céria como material bastante promissor para misturas de $\mathrm{H}_{2} / \mathrm{CO}$ [32], consequentemente, estudos sobre eletrocatalisadores com $2 \%$ em peso de Platina sobre $\mathrm{Ce}_{0,9} \mathrm{M}_{0,1} \mathrm{O}_{x}$ para oxidação de $\mathrm{CO}$ [25] foram selecionados para este trabalho.

\subsection{Rutênio}

O Rutênio é um metal de transição, que em temperatura ambiente encontra-se em estado sólido. Em seus compostos, o rutênio apresenta diferentes estados de oxidação, alcançando inclusive o estado +8 , mas os mais comuns são $+2,+3$ e +4 .

Reagindo com água, o rutênio forma o dióxido de rutênio, que possui estrutura cristalina tetragonal (Figura 9), tendo seu ponto de sublimação em $1200^{\circ} \mathrm{C}$.

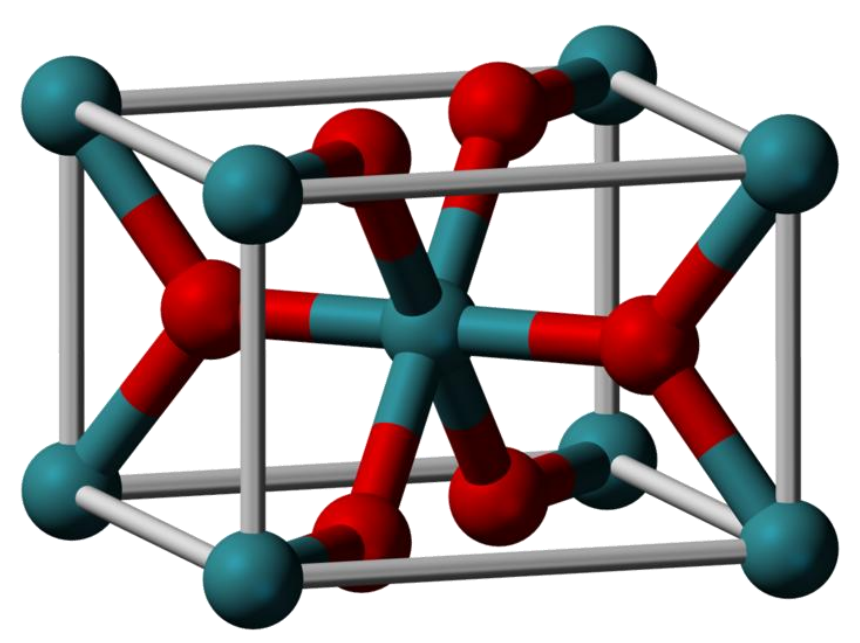

FIGURA 9. Estrutura cristalina tetragonal do dioxido de rutênio, onde - representa o oxigênio e representa o rutênio [33]. 
A utilização do rutênio como co-catalisador junto com a platina melhora consideravelmente o desempenho da célula [2], já que fornece espécies oxigenadas na vizinhança da platina envenenada, oxidando o $\mathrm{CO}$ a $\mathrm{CO}_{2}$ a menores valores de potenciais, liberando assim os sítios ativos da Platina para novas adsorções. Os mecanismos co-catalíticos do rutênio que ocorrem um células tipo PEM são (Eq. 7-9) [2]:

$$
\begin{array}{ll}
\mathrm{Ru}\left(\mathrm{H}_{2} \mathrm{O}\right) \rightarrow \mathrm{RuOH}+\mathrm{H}^{+}+\mathrm{e}^{-} & \text {Equação 7 } \\
\mathrm{Pt}(\mathrm{CO})_{\text {ads }}+\mathrm{RuOH} \rightarrow \mathrm{Pt}+\mathrm{Ru}+\mathrm{CO}_{2}+\mathrm{H}^{+}+\mathrm{e}^{-} & \text {Equação 8 } \\
\mathrm{Ru}(\mathrm{CO})_{\text {ads }}+\mathrm{RuOH} \rightarrow 2 \mathrm{Ru}+\mathrm{CO}_{2}+\mathrm{H}^{+}+\mathrm{e}^{-} & \text {Equação 9 }
\end{array}
$$

\subsection{Terras Raras}

O nome "terras raras" é empregado para os elementos que dificilmente se separam [34]. Os lantanídeos em conjunto com o ìtrio e o escândio são considerados terras raras, e estes, geralmente, ocorrem na natureza juntos, no mineral monazita e gadolinita, xenotima, bastnaesita entre outros.

Esses elementos são alocados em uma série isolada do bloco principal da tabela periódica, já que os elétrons mais externos desses elementos ocupam o nível $\mathrm{n}=4$ e o orbital $4 \mathrm{f}$ é preenchido por elétrons. Este bloco fica na horizontal, já que a periodicidade das propriedades dos elementos aparece com o aumento do número atômico [35].

As terras raras, em condições normais de temperatura e pressão, reagem facilmente com $o$ ar atmosférico, formando óxidos muito estáveis na presença de oxigênio [36]. No estado de óxido, três elétrons são removidos do átomo, deixando a configuração $\mathrm{f}^{\mathrm{n}}(\mathrm{n}=0$ a 14).

O Ce e o Y são as terras raras mais abundantes na crosta terrestre.

\subsection{1. Óxido de Cério (IV)}

A céria (óxido de cério IV) tem estrutura cristalina cúbica do tipo fluorita, sendo assim, é estável em temperatura ambiente. Nesta estrutura cristalina, o cério tem número de coordenação 8 , assim, cada íon de cério (IV) 
tem oito íons de oxigênio como vizinhos mais próximos e como o oxigênio tem número de coordenação 4, cada íon de oxigênio possui quatro íons de cério (IV) como vizinhos, conforme Figura 10.

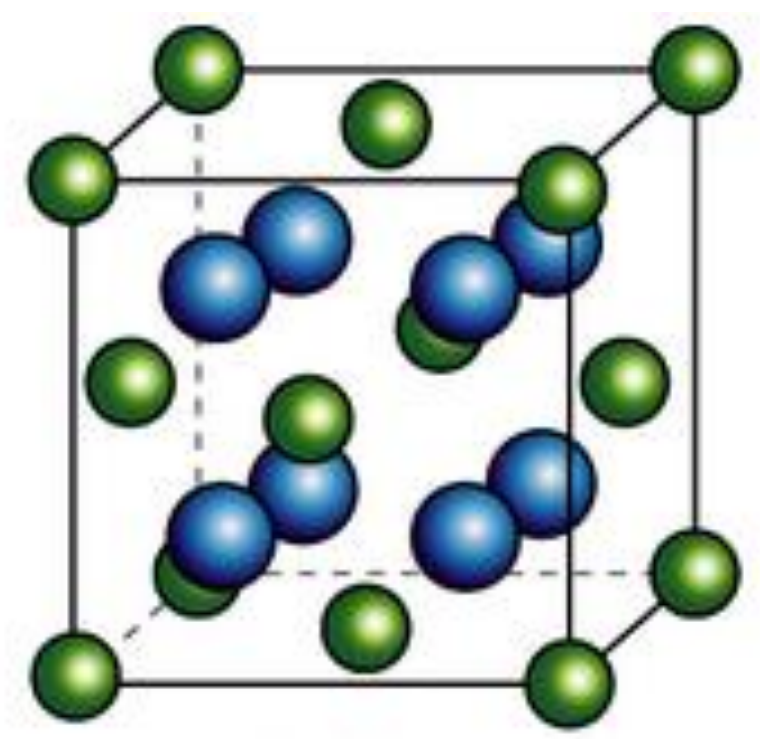

FIGURA 10. Estrutura tipo Fluorita da Céria, onde representa o oxigênio e representa o cério [37].

A $\mathrm{CeO}_{2}$ é um dos óxidos mais interessantes industrialmente, já que os defeitos, como as vacâncias de oxigênio, podem ser rapidamente formados e eliminados, aumentando a capacidade de armazenar oxigênio, e assim melhorando a atividade de alguns catalisadores. Estes defeitos podem ser formados pela adição de óxidos menos redutíveis na estrutura da céria, que juntamente com metais de transição, tornam-se bons catalisadores para as reações de reforma a vapor e reações de oxidação de monóxido de carbono [38].

Esche e colaboradores [39], através de uma imagem de microscopia de tunelamento, mostram que as vacâncias da $\mathrm{CeO}_{2}$ (111) são imóveis em temperatura ambiente, mas que com uma temperatura mais elevada, formam-se "clusters" (aglomerados) de íons $\mathrm{Ce}^{3+}$, assim, estes "clusters" de íons $\mathrm{Ce}^{3+}$ são expostos aos reagentes gasosos, Figura 11. Os "clusters" provenientes da $\mathrm{CeO}_{2}$ são muito importantes na catálise, já que os gases participantes de uma reação podem interagir simultaneamente com vários íons $\mathrm{Ce}^{3+}$, aumentando a capacidade de oxidar estes gases [38]. 


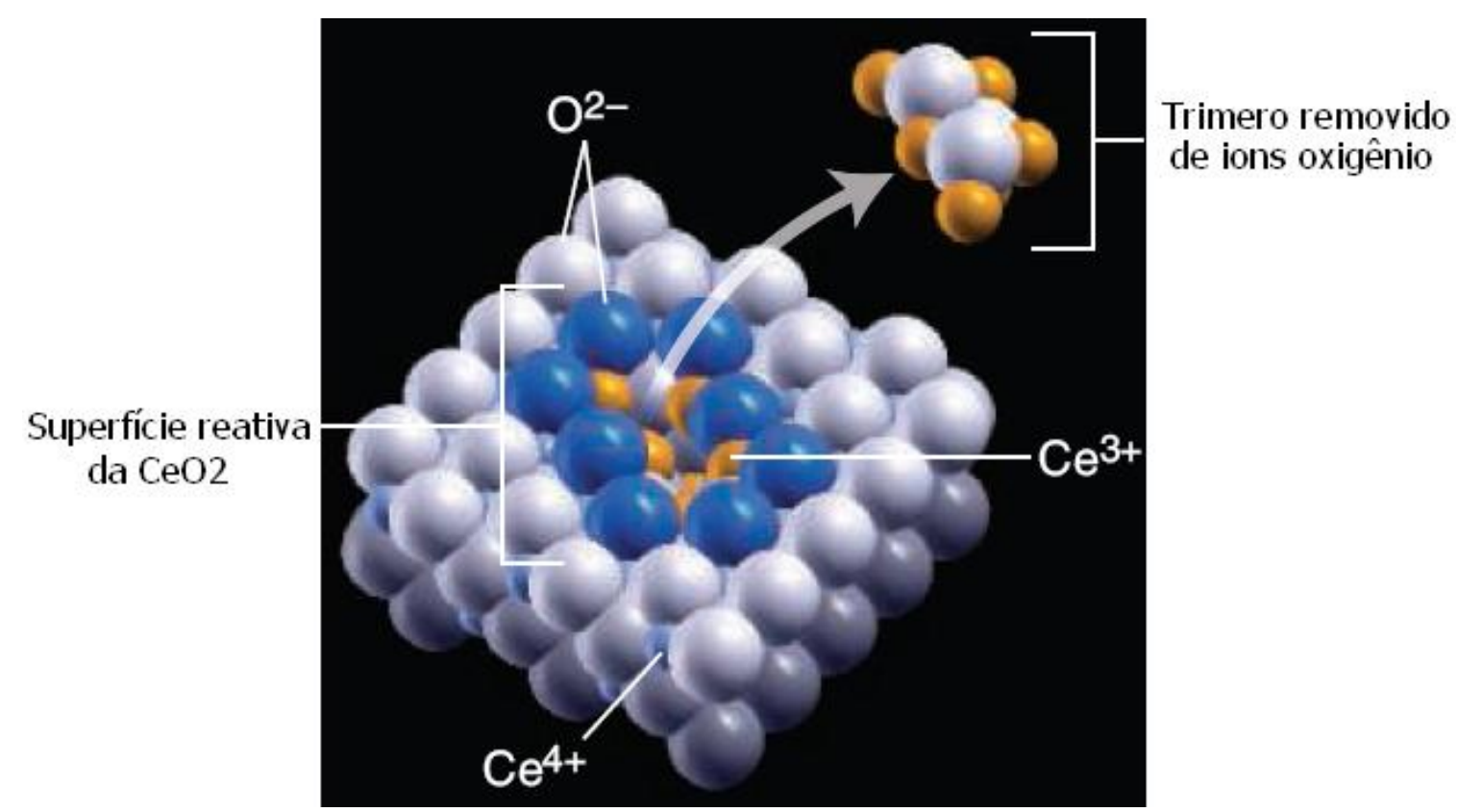

FIGURA 11. Defeito reativo na superfície da Céria [39].

A energia de formação da vacância de oxigênio é resultado de três contribuições: $E_{f}=E_{1}+E_{2}+E_{3}$, sendo que a $E_{1}$ representa a excitação eletrônica $\mathrm{O}^{2-}+2 \mathrm{Ce}^{4+} \rightarrow \mathrm{O}+2 \mathrm{Ce}^{3+}, \mathrm{E}_{2}$ representa a remoção do átomo de oxigênio e $\mathrm{E}_{3}$ representa o relaxamento [40], Figura 12.

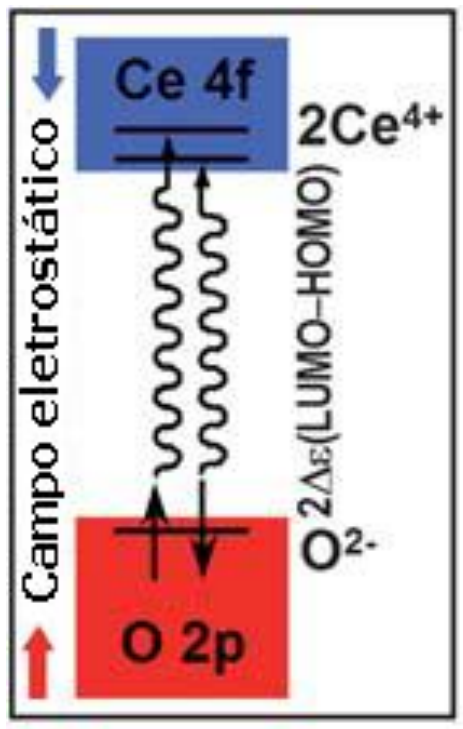

$\mathrm{E}_{1}$

$$
E_{f}=E_{1}+E_{2}+E_{3}
$$

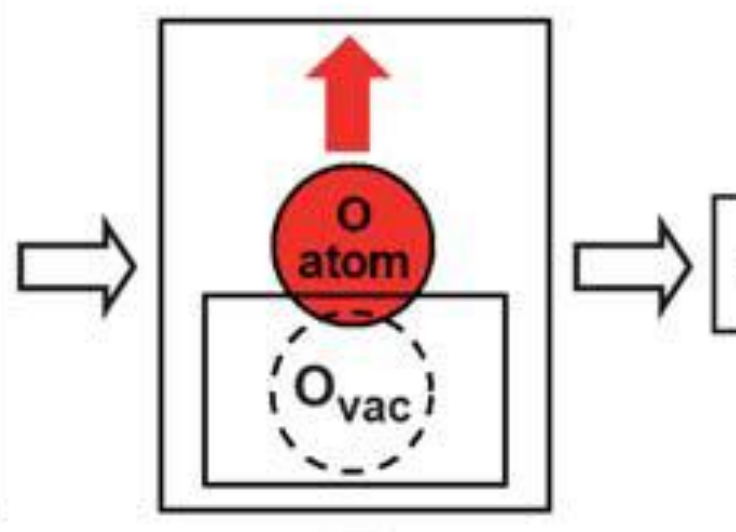

$\mathrm{E}_{2}$
Relaxamento

$E_{3}$

FIGURA 12. Etapas elementares da criação da vacância de oxigênio em Céria [40]. 


\subsection{2. Ítria}

A ítria (oxido de ítrio III) tem estrutura cristalina cúbica de corpo centrado (Figura 13), tendo solubilidade extensa na estrutura cristalina fluorita. Nesta estrutura, cada ion de ítrio (III) coordena com 6 ions de oxigênio, sendo que estes podem assumir dois diferentes arranjos espaciais formando um cubo com dois vértices não ocupados.

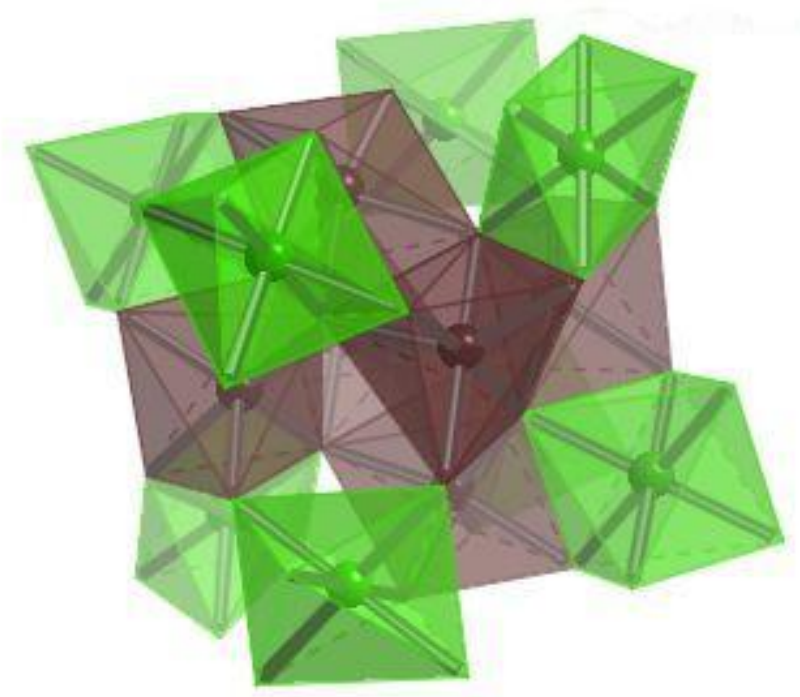

FIGURA 13. Estrutura cristalina do óxido de ítrio (III)[41].

\subsection{Dopagem da Céria}

Quando se faz a dopagem da céria, $\mathrm{CeO}_{2}$, com óxidos de elementos lantanídeos, há formação de solução sólida do tipo substitucional, onde o cátion dopante assume a posição do cátion hospedeiro.

\subsection{1. $\mathrm{Ce}_{0,9} \mathrm{Y}_{0,1} \mathrm{O}_{2}$}

A solução sólida, para baixas concentrações de $\mathrm{Y}_{2} \mathrm{O}_{3}$ apresenta a mesma estrutura cristalina da $\mathrm{CeO}_{2}$, (Figura 14). Mudando apenas o parâmetro de rede, já que devido à diferença de valência entre os cátions hospedeiro $\left(\mathrm{Ce}^{4+}\right) \mathrm{e}$ dopante $\left(\mathrm{Y}^{3+}\right)$, são necessariamente formados defeitos complementares, criando- 
se vacâncias aniônicas, que mantém a condição de neutralidade elétrica da estrutura.
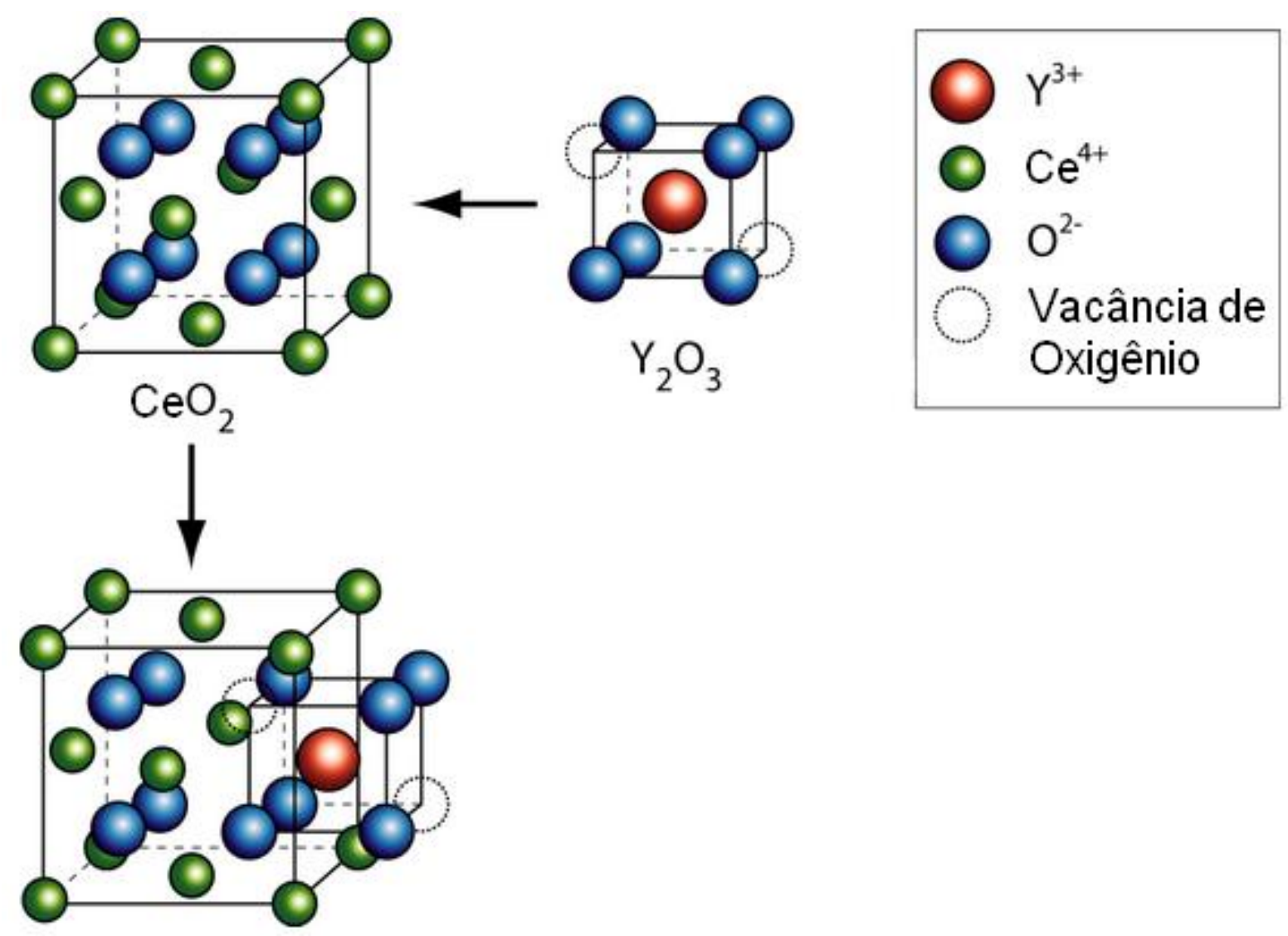

FIGURA 14. Estrutura cristalina da solução sólida $\mathrm{Ce}_{0,9} \mathrm{Y}_{0,1} \mathrm{O}_{2}$ [42].

Como a estrutura da itria é muito pequena, ela funciona como dopante da céria, que é um cátion maior. Dopar envolve geralmente a adição de cátions de menor valência na estrutura, com a finalidade de manter as vacâncias de oxigênio, permitindo assim a migração de íons de oxigênio. A estrutura aberta e desordenada resultante da dopagem, é que promove a condução iônica, Figura 15 [40]. 


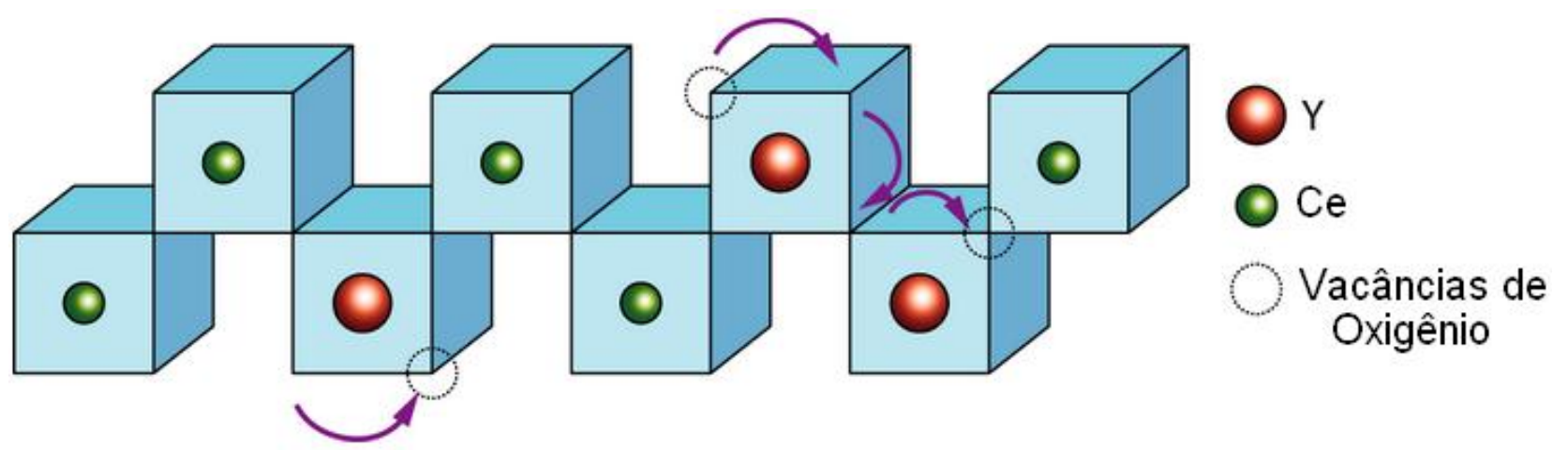

FIGURA 15. Condução iônica na céria dopada com itria. 


\section{METODOLOGIA EXPERIMENTAL}

\subsection{Preparação dos eletrocatalisadores}

Os suportes para catalisadores, $\mathrm{Ce}_{0,9} \mathrm{Y}_{0,1} \mathrm{O}_{2}$ e $\mathrm{Ce}_{0,9} \mathrm{Ru}_{0,1} \mathrm{O}_{2}$, utilizados neste trabalho, foram preparados utilizando uma versão modificada do método relatado por Inomata e colaboradores [43]. Os óxidos mistos foram sintetizados diretamente através da fervura de soluções de nitrato de seus precursores, sob vácuo, seguido de calcinação [44]. No suporte de $\mathrm{Ce}_{0,9} \mathrm{Ru}_{0,1} \mathrm{O}_{2}$ ainda foram adicionados $15 \%$ em massa de $\mathrm{RuO}_{2}$.

\subsubsection{Preparação dos eletrocatalisadores $\mathrm{Pt}:\left(\mathrm{Ce}_{0,9} \mathrm{Y}_{0,1} \mathrm{O}_{2}\right)+\mathrm{Pt} / \mathrm{C}$ Etek e $\mathrm{Pt}:\left(\mathrm{Ce}_{0,9} \mathrm{Ru}_{0,1} \mathrm{O}_{2}+\mathrm{RuO} \mathrm{O}_{2}\right)+\mathrm{Pt} / \mathrm{C}$ Etek}

A ancoragem da nanopartícula de platina dos eletrocatalisadores $\mathrm{Pt}:\left(\mathrm{Ce}_{0,9} \mathrm{Y}_{0,1} \mathrm{O}_{2}\right)+\mathrm{Pt} / \mathrm{C}$ Etek e Pt: $\left(\mathrm{Ce}_{0,9} \mathrm{Ru}_{0,1} \mathrm{O}_{2}+\mathrm{RuO}_{2}\right)+\mathrm{Pt} / \mathrm{C}$ Etek foi obtida pelo método de redução por álcool desenvolvido no IPEN-CNEN/SP [45]. Para preparação destes eletrocatalisadores, utilizou-se o ácido hexacloroplatínico $\left(\mathrm{H}_{2} \mathrm{PtCl}_{6} .6 \mathrm{H}_{2} \mathrm{O}\right.$-Aldrich) como fonte de platina, e o etileno glicol (Merck) como agente redutor e estabilizante, ao mesmo tempo.

Dissolveu-se o $\mathrm{H}_{2} \mathrm{PtCl}_{6} \cdot 6 \mathrm{H}_{2} \mathrm{O}$ em uma solução de etileno glicol/água 3:1 (v/v), logo depois adicionou-se a $\mathrm{Ce}_{0,9} \mathrm{Y}_{0,1} \mathrm{O}_{2}$ (ou a $\mathrm{Ce}_{0,9} \mathrm{Ru}_{0,1} \mathrm{O}_{2}+\mathrm{RuO}_{2}$ ). Levou-se a mistura em banho de ultrassom por 5 minutos e logo após esta foi submetida ao processo de refluxo por 3 horas. Então filtrou-se a mistura e o sólido resultante foi lavado com 4 Litros de água para remover íons cloretos e posteriormente seco em uma estufa a $70^{\circ} \mathrm{C}$ por 2 horas (Figura 16). 


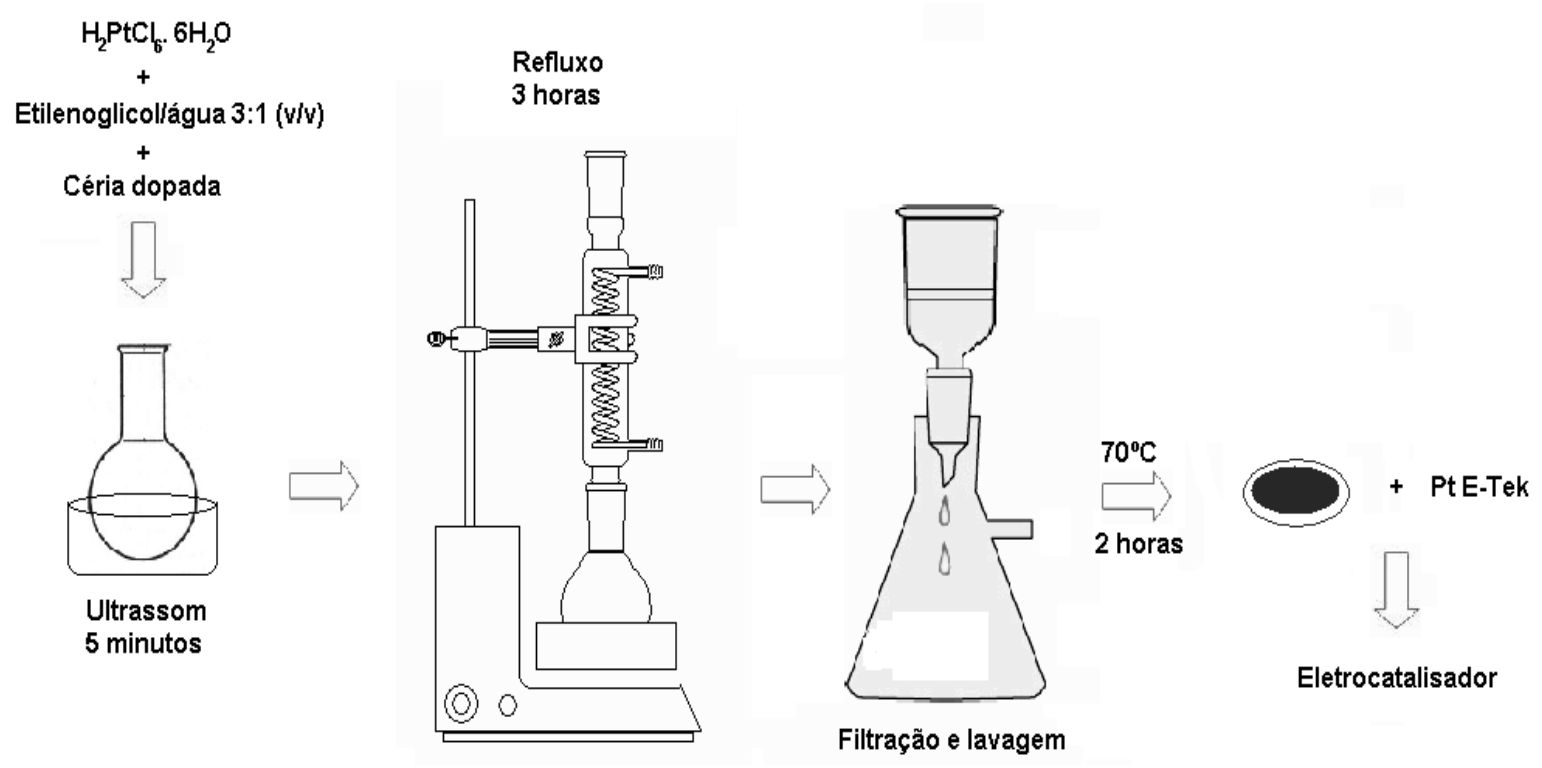

FIGURA 16. Esquema de preparação dos eletrocatalisadores $\mathrm{Pt}: \mathrm{Ce}_{0,9} \mathrm{Y}_{0,1} \mathrm{O}_{2}+\mathrm{Pt} / \mathrm{C}$ Etek e Pt: $\mathrm{Ce}_{0,9} \mathrm{Ru}_{0,1} \mathrm{O}_{2}+\mathrm{RuO}_{2}+\mathrm{Pt} / \mathrm{C}$ Etek

Os eletrocatalisadores Pt: $\mathrm{Ce}_{0,9} \mathrm{Y}_{0,1} \mathrm{O}_{2}+\mathrm{Pt} / \mathrm{C}$ Etek e Pt: $\mathrm{Ce}_{0,9} \mathrm{Ru}_{0,1} \mathrm{O}_{2}+\mathrm{RuO}_{2}+\mathrm{Pt} / \mathrm{C}$ Etek foram preparados com $2 \%$ de $\mathrm{Pt}$ em massa de $\mathrm{Ce}_{0,9} \mathrm{Y}_{0,1} \mathrm{O}_{2}$ ou $\mathrm{Ce}_{0,9} \mathrm{Ru}_{0,1} \mathrm{O}_{2}+\mathrm{RuO}_{2}$, tendo como base estudos prévios de Tibiletti e colaborados [46]. Estes sistemas anteriormente preparados foram adicionados com Pt/C Etek, sob mistura mecânica, preparando eletrocatalisadores de $\mathrm{Pt}: \mathrm{Ce}_{0,9} \mathrm{Y}_{0,1} \mathrm{O}_{2}+\mathrm{Pt} / \mathrm{C}$ Etek e Pt: $\mathrm{Ce}_{0,9} \mathrm{Ru}_{0,1} \mathrm{O}_{2}+\mathrm{RuO}_{2}+\mathrm{Pt} / \mathrm{C}$ Etek com 15\% em massa $\mathrm{Ce}_{0,9} \mathrm{Y}_{0,1} \mathrm{O}_{2}$ ou $\mathrm{Ce}_{0,9} \mathrm{Ru}_{0,1} \mathrm{O}_{2}+\mathrm{RuO}_{2}$ de forma a garantir a porcentagem de $20 \%$ da Pt nestes catalisadores.

\subsubsection{Preparação dos eletrocatalisadores $\mathrm{Pt}: \mathrm{Ce}_{0,9} \mathrm{Y}_{0,1} \mathrm{O}_{2} / \mathrm{C}$, $\mathrm{Pt}: \mathrm{Ce}_{0,9} \mathrm{Ru}_{0,1} \mathrm{O}_{2}+\mathrm{RuO}_{2} / \mathrm{C}$}

A ancoragem da nanopartícula de platina dos eletrocatalisadores Pt:Ce $e_{0,9} \mathrm{Y}_{0,1} \mathrm{O}_{2} / \mathrm{C}$ e Pt:Ce $e_{0,9} \mathrm{Ru}_{0,1} \mathrm{O}_{2}+\mathrm{RuO}_{2} / \mathrm{C}$ foi obtida pelo método da redução por álcool [45]. Para preparação destes, utilizou-se o $\mathrm{H}_{2} \mathrm{PtCl}_{6} \cdot 6 \mathrm{H}_{2} \mathrm{O}$ (Aldrich), o etileno glicol (Merck) e o Carbon Vulcan XC72R . Dissolveu-se o $\mathrm{H}_{2} \mathrm{PtCl}_{6} \cdot 6 \mathrm{H}_{2} \mathrm{O}$ em uma solução de etileno glicolágua $3: 1(\mathrm{v} / \mathrm{v})$, logo depois adicionou-se a $\mathrm{Ce}_{0,9} \mathrm{Y}_{0,1} \mathrm{O}_{2}$ (ou a $\mathrm{Ce}_{0,9} \mathrm{Ru}_{0,1} \mathrm{O}_{2}+\mathrm{RuO}_{2}$ ) e o suporte de carbono. Levou-se a mistura em banho de ultrassom por 5 minutos e logo após esta foi submetida a 
refluxo por 3 horas. Então filtrou-se a mistura e o sólido resultante foi lavado com água e seco a $70^{\circ} \mathrm{C}$ por 2 horas (Figura 17).

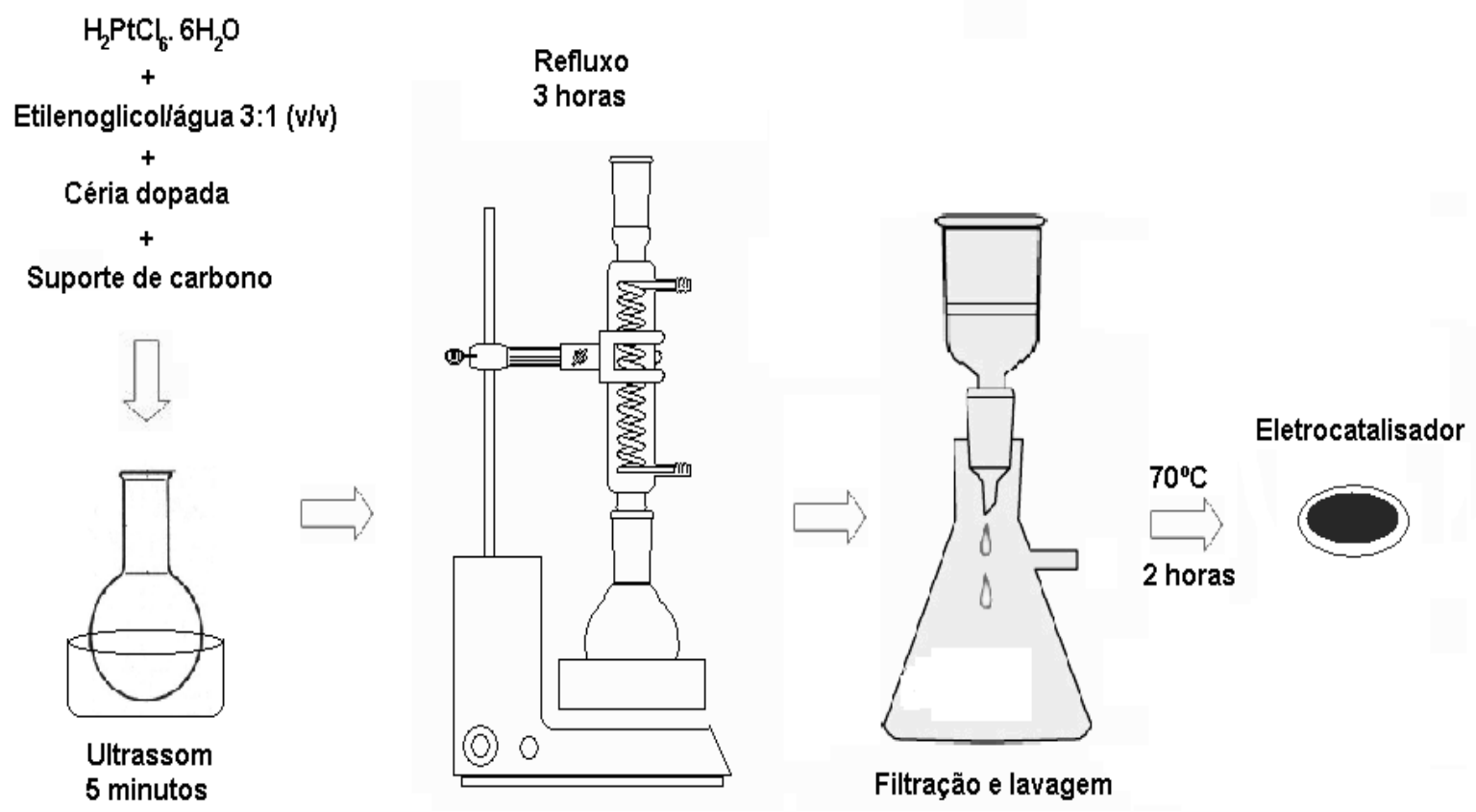

FIGURA 17. Esquema de preparação dos eletrocatalisadores $\mathrm{Pt}_{\mathrm{A}} \mathrm{Ce}_{0,9} \mathrm{Y}_{0,1} \mathrm{O}_{2} / \mathrm{C} \mathrm{e}$ Pt: $\mathrm{Ce}_{0,9} \mathrm{Ru}_{0,1} \mathrm{O}_{2}+\mathrm{RuO}_{2} / \mathrm{C}$

Os eletrocatalisadores Pt: $\mathrm{Ce}_{0,9} \mathrm{Y}_{0,1} \mathrm{O}_{2} / \mathrm{C}$ e Pt: $\mathrm{Ce}_{0,9} \mathrm{Ru}_{0,1} \mathrm{O}_{2}+\mathrm{RuO}_{2} / \mathrm{C}$ foram preparados com $20 \%$ de $\mathrm{Pt}$ em massa e $15 \%$ de $\mathrm{Ce}_{0,9} \mathrm{Y}_{0,1} \mathrm{O}_{2}$ ou $\mathrm{Ce}_{0,9} \mathrm{Ru}_{0,1} \mathrm{O}_{2}+\mathrm{RuO}_{2}$ dos $80 \%$ em massa do suporte de carbono, conforme estudos de Neto e colaboradores, onde mostraram que os eletrocatalisadores com 15\% em peso de $\mathrm{CeO}_{2}$ para eletro oxidação do etanol obtiveram os melhores desempenhos para a oxidação eletroquímica do etanol [47].

\subsection{Caracterização dos eletrocatalisadores}

\subsubsection{Análise de difração de raio $X(D R X)$}

Realizou-se a análise de DRX com o objetivo de obter informações da estrutura cristalina e estimar o tamanho médio de cristalito dos catalisadores. Para esta análise utilizou-se um difratômetro Rigaku modelo Miniflex II com radiação CuKa no intervalo de $2 \Theta$ de $20^{\circ}$ - $90^{\circ}$ com velocidade de varredura de 
$2^{\circ} \cdot \min ^{-1}$. Estimou-se o tamanho médio de cristalito utilizando-se a equação de Scherrer (Equação 10) [48].

$$
d=\frac{K \cdot \lambda}{\beta_{(2 \theta)} \cdot \cos \theta_{\max }}
$$

Sendo d o diâmetro médio dos cristalitos em Angstrons, $\mathrm{K}$ uma constante que depende da forma dos cristalitos, sendo utilizado o valor $K=0,9$ admitindo cristalitos esféricos; $\lambda$ representando o comprimento de onda da radiação usada, $\mathrm{Cu} \lambda=1,54056 \AA ; \beta$ sendo a largura a meia altura do pico em radianos e $\Theta$ sendo o ângulo de Bragg em graus para o ponto máximo do pico analisado.

\subsubsection{Análise de microscopia eletrônica de transmissão (MET)}

Realizou-se a análise de MET com a finalidade de obter informações sobre o tamanho, distribuição de tamanhos e o grau de cristalinidade das nanopartículas. Para realização desta, dispersou-se as amostras sobre a grade de cobre $(0,3 \mathrm{~cm}$ de diâmetro) e utilizou-se um Microscópio Eletrônico de Transmissão JEOL modelo JEM-2100 (200 kV).

\subsection{Fabricação do conjunto eletrodos-membrana (MEA)}

\subsubsection{Tratamento das membranas de Nafion ${ }^{\circledR}$}

Utilizou-se neste trabalho a membrana Nafion®115 (Du Pont), com espessura de $127 \mu \mathrm{m}$ e área de $5 \mathrm{~cm}^{2}$. O tratamento das membranas visa a remoção de possíveis contaminantes orgânicos e inorgânicos presentes na membrana.

Tratou-se as membranas com peróxido de hidrogênio $\left(\mathrm{H}_{2} \mathrm{O}_{2} 3 \%\right)$ e ácido sulfúrico $\left(\mathrm{H}_{2} \mathrm{SO}_{4} \quad 0,5 \mathrm{~mol}^{-1} \mathrm{~L}^{-1}\right)$ a $80^{\circ} \mathrm{C}$ por 1 hora, sendo entre estes tratamentos, as membranas passaram por três lavagens com água ultra-pura a $80^{\circ} \mathrm{C}$ por 1 hora em cada lavagem, conforme Figura 18. Depois do tratamento, as 
membranas foram acondicionadas imersas em água deionizada em um frasco com tampa.

Lavagem:

$\mathrm{H}_{2} \mathrm{O} 80^{\circ} \mathrm{C} / \mathrm{lh}$

Nafion ${ }^{(\mathrm{K})} 115$
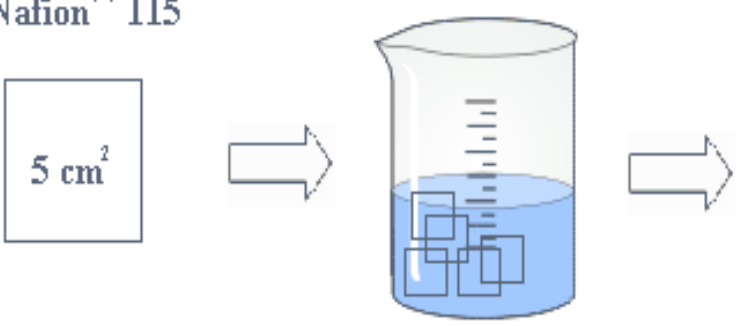

Tratamento:

Lavagem:

$\mathrm{H}_{2} \mathrm{O} 80^{\circ} \mathrm{C} / \mathrm{lh}$

$(3 \mathrm{X})$
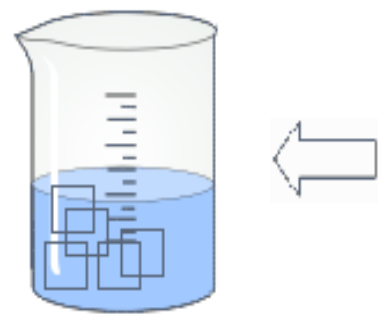

$\mathrm{H}_{4} \mathrm{SO}_{4} 0,5 \mathrm{~mol} . \mathrm{L}^{-1} 80^{\circ} \mathrm{C} / \mathrm{lh}$
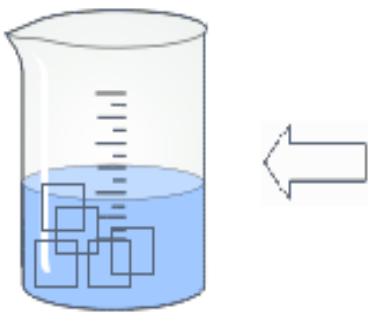

Tratamento:

$\mathrm{H}_{2} \mathrm{O}_{2} 3 \% 80^{\circ} \mathrm{C} / \mathrm{lh}$
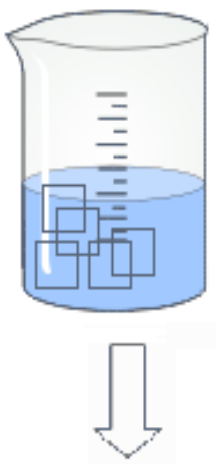

Lavagem:

$\mathrm{H}_{2} \mathrm{O} 80^{\circ} \mathrm{C} / \mathrm{lh}$
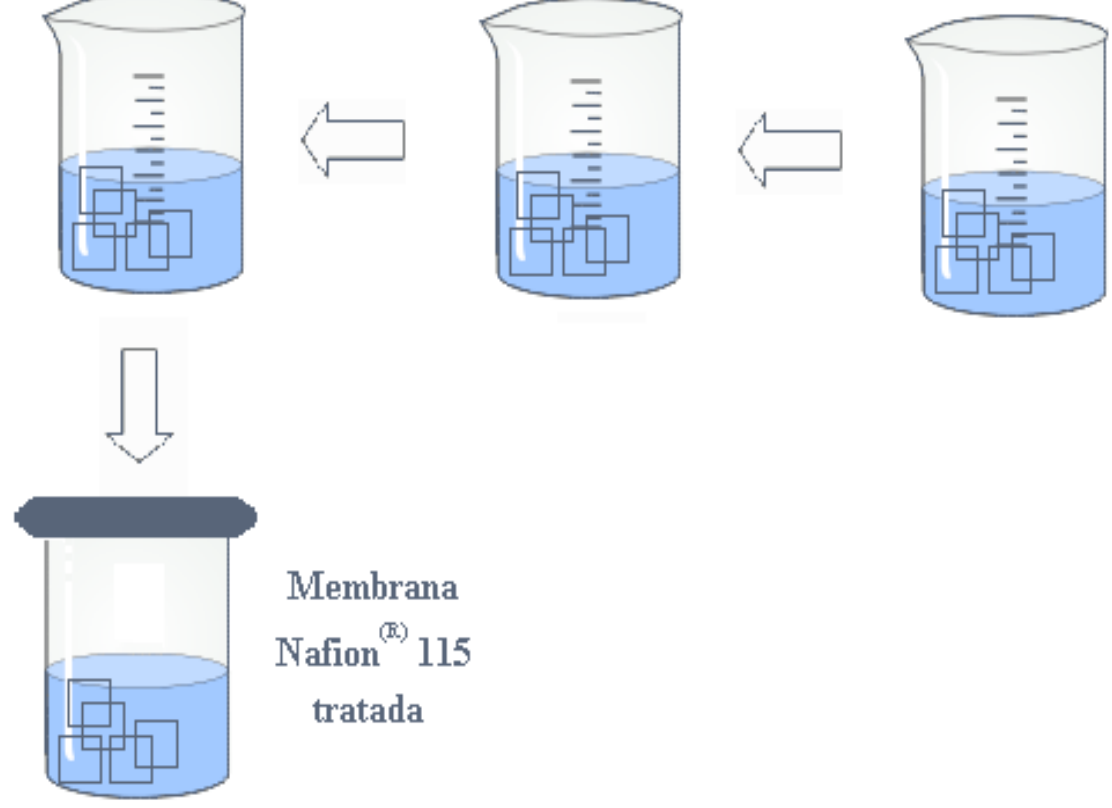

Membrana

Nafion $^{(\mathrm{K})} 115$

tratada

FIGURA 18. Procedimento para tratamento da Membrana Nafion ${ }^{\circledR} 115$.

\subsubsection{Camada catalisadora}

Na fabricação do MEA, formou-se a camada difusora de gás através da deposição de uma mistura de Vulcan XC-72R (Cabot) e politetrafluoretileno (PTFE-TE-306 A, Dupont) em um tecido de carbono (EC-CC1-060T).

A camada catalisadora do ânodo foi preparada utilizando-se eletrocatalisador de Pt:Ce ${ }_{0,9} \mathrm{Y}_{0,1} \mathrm{O}_{2}+\mathrm{Pt} / \mathrm{C}$ Etek, Pt: $\mathrm{Ce}_{0,9} \mathrm{Ru}_{0,1} \mathrm{O}_{2}+\mathrm{RuO}_{2}+\mathrm{Pt} / \mathrm{C}$ Etek, 
Pt:Ce $e_{0,9} \mathrm{Y}_{0,1} \mathrm{O}_{2} / \mathrm{C}$ ou Pt:Ce $e_{0,9} \mathrm{Ru}_{0,1} \mathrm{O}_{2}+\mathrm{RuO}_{2} / \mathrm{C}$. Já na camada catalisadora do cátodo, utilizou-se uma carga de $0,4 \mathrm{mg} \mathrm{Pt.cm}{ }^{-2}$ do eletrocatalisador comercial Pt/C ETek 20\%, utilizando-se, tanto para o cátodo quanto para o ânodo, 1,1mg $\mathrm{cm}^{-2}$ de solução de Nafion $5 \%$.

Os eletrocatalisadores foram depositados sobre o tecido de carbono através da técnica de pintura por pincel. Após a pintura, colocou-se os eletrodos na estufa a $75^{\circ}$ por duas horas para secagem (Figura 19).

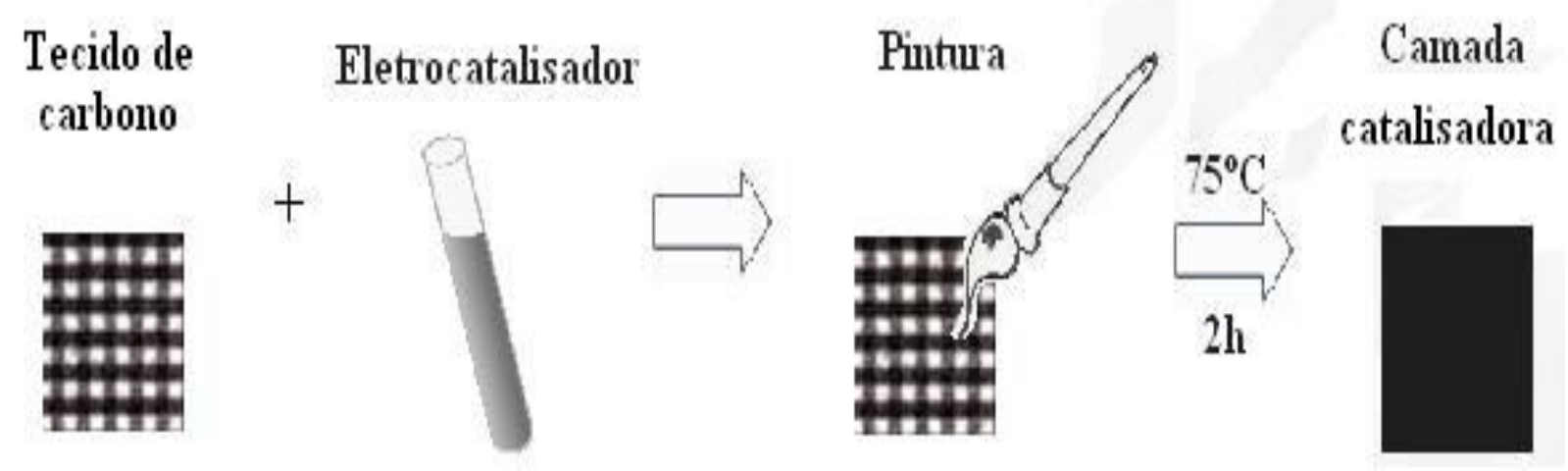

FIGURA 19. Procedimento de preparação da camada catalisadora.

\subsubsection{Conjunto eletrodo-membrana-eletrodo (MEA)}

Preparou-se o MEA por prensagem a quente $\left(125^{\circ} \mathrm{C}\right)$ e pressão de cinco toneladas (ou $1.000 \mathrm{Kgf.cm}^{-2}$ ) por 2 minutos. Este pocesso visa melhorar o contato elétrico entre a membrana e a camada catalisadora.

Para evitar o vazamento de gases, prensou-se o MEA entre dois espaçadores (molduras de fibra de vidro vazadas), de forma a deixar exposta somente a camada catalisadora (Figura 20). 

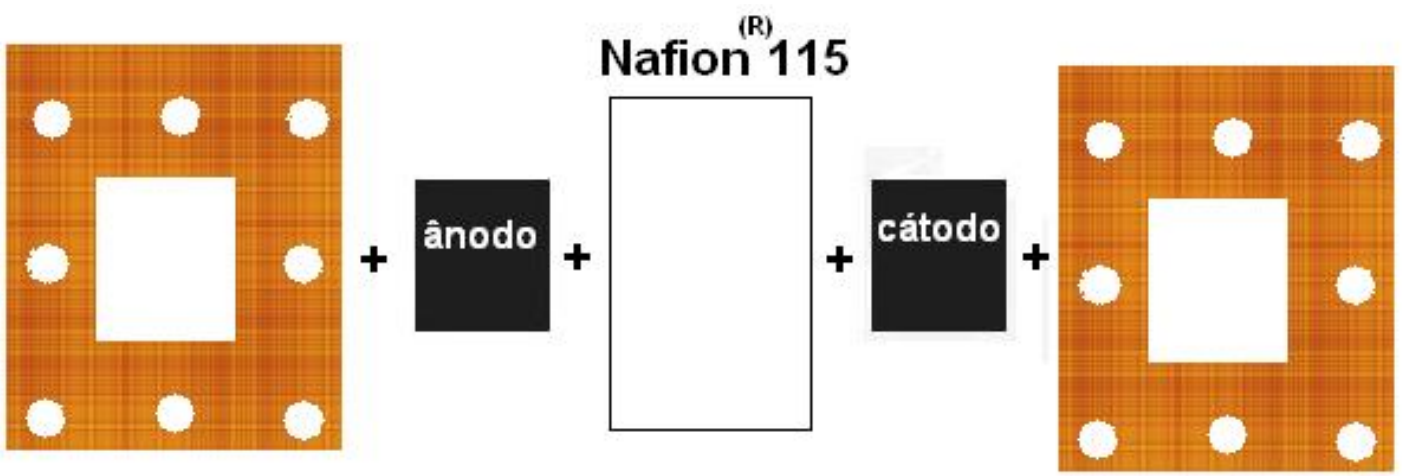

Espaçador

Espaçador

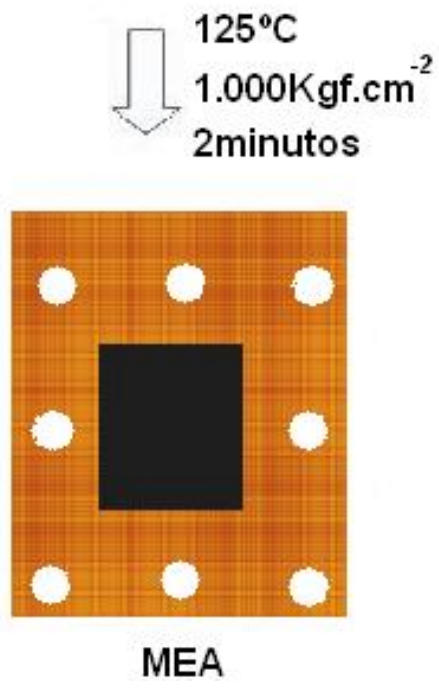

FIGURA 20. Esquema da fabricação do MEA.

Com o MEA fabricado, utilizou-se uma célula unitária da Eletrocell com placas de grafite do tipo serpentina (para distribuição dos gases) com 5 $\mathrm{cm}^{2}$ de área geométrica ativa (Figura 21). 


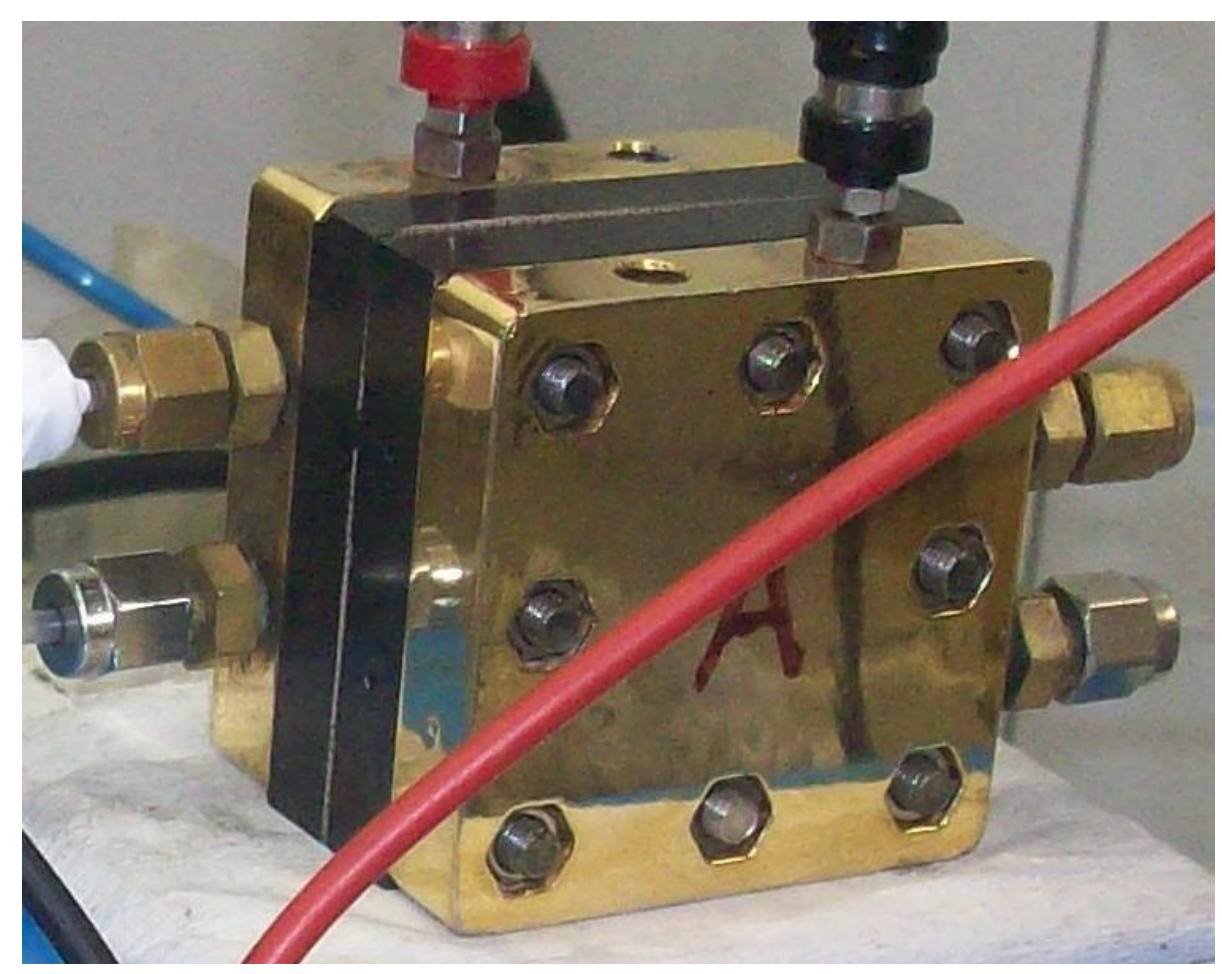

FIGURA 21. Célula a combustível unitária da Eletrocell com placas de grafite.

\subsection{Stripping de CO}

Realizou-se experimentos de varredura linear de potencial de oxidação de $\mathrm{CO}$ (stripping de $\mathrm{CO}$ ) em eletrodos de difusão de gás em uma célula de 3 eletrodos em temperatura ambiente ( $\left.25^{\circ} \mathrm{C}\right)$. O ânodo, baseado em $\mathrm{Pt}: \mathrm{CeYO}_{2} / \mathrm{C}$, $\mathrm{Pt}:\left(\mathrm{Ce}_{0,9} \mathrm{Ru}_{0,1} \mathrm{O}_{2}+\mathrm{RuO}_{2}\right) / \mathrm{C}, \mathrm{Pt}: \mathrm{Ce}_{0,9} \mathrm{Y}_{0,1} \mathrm{O}_{2}+\mathrm{Pt} / \mathrm{C}$ Etek ou Pt: $\left(\mathrm{Ce}_{0,9} \mathrm{Ru}_{0,1} \mathrm{O}_{2}+\mathrm{RuO}_{2}\right)$ + Pt/C Etek, foi mantido como eletrodo de trabalho, e o cátodo, baseado em Pt/C Etek, foi considerado contra-eletrodo e eletodo de referência de hidrogênio, sendo que para isto, o cátodo esteve sob alimentação contínua de hidrogênio.

Para realização das medidas, o eletrodo de trabalho foi desoxigenado previamente com $\mathrm{N}_{2}$. Assim, obteve-se um voltamograma cíclico na ausência de $\mathrm{CO}$ no intervalo de potenciais de 0,1 a $0,9 \mathrm{~V}$ vs $\mathrm{ERH}$ ( eletrodo de referência de Hidrogênio) com velocidade de varredura de $20 \mathrm{mV} . \mathrm{s}^{-1}$. Logo após, alimentou-se o eletrodo de trabalho com uma mistura de $\mathrm{H}_{2} / \mathrm{CO}$ (1000 ppm) polarizado em 0,2 V por 15 minutos. Retirou-se o possível excesso de CO purgando $\mathrm{N}_{2}$ por 20 minutos. Então, realizou-se o stripping de $\mathrm{CO}$ no intervalo de 0,1 a $0,9 \mathrm{~V}$ vs $\mathrm{ERH}$ com velocidade de varredura de $20 \mathrm{mV} . \mathrm{s}^{-1}$. 
Para este procedimento, utilizou-se um potenciostato-galvanostato (Autolab), ligado ao booster active (BSTR10A-Autolab), acoplados a um computador, conforme Figura 22.

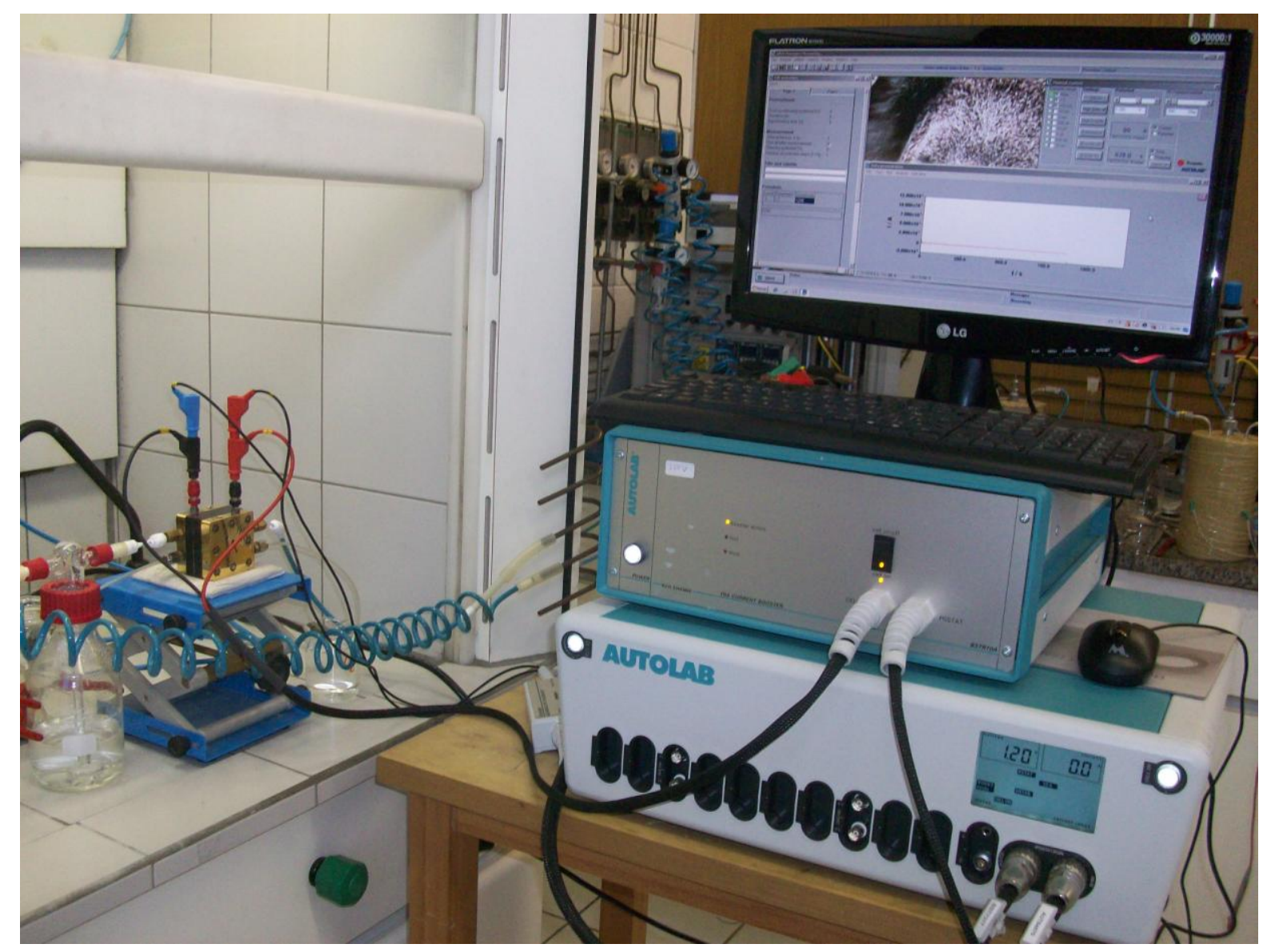

FIGURA 22. Sistema utilizado no experimento de varredura linear de oxidação de CO.

\subsection{Medidas de polarização em célula a combustível unitária alimentada com $\mathrm{H}_{2}$ puro e $\mathrm{H}_{2} / \mathrm{CO}$}

Com o MEA preparado e a célula montada (Figura 23) aqueceu-se os gases $\mathrm{H}_{2}$ puro (ou $\mathrm{H}_{2} / \mathrm{CO}$ ), $\mathrm{O}_{2}$ e a célula a temperaturas de 100,90 e $85^{\circ}$ respectivamente. Com os gases e a célula na temperatura desejada, ativou-se a célula e estabilizou-se em $0,6 \mathrm{~V}$, por ser o potencial de oxidação do hidrogênio, por 2 horas. Logo após, efetuou-se as medidas de polarização com $\mathrm{H}_{2}$ puro e $\mathrm{O}_{2}$, sob uma pressão de 2 atm na saída de ambos os gases da célula. Obtidas as 
curvas de polarização para $\mathrm{H}_{2}$ puro, trocou-se o gás $\mathrm{H}_{2}$ por uma mistura de $\mathrm{H}_{2} / \mathrm{CO}$ 100 ppm, estabilizando a célula a $0,8 \mathrm{~V}$, por ser o potencial de oxidação do CO, por 2 horas, obteve-se a curva de polarização.

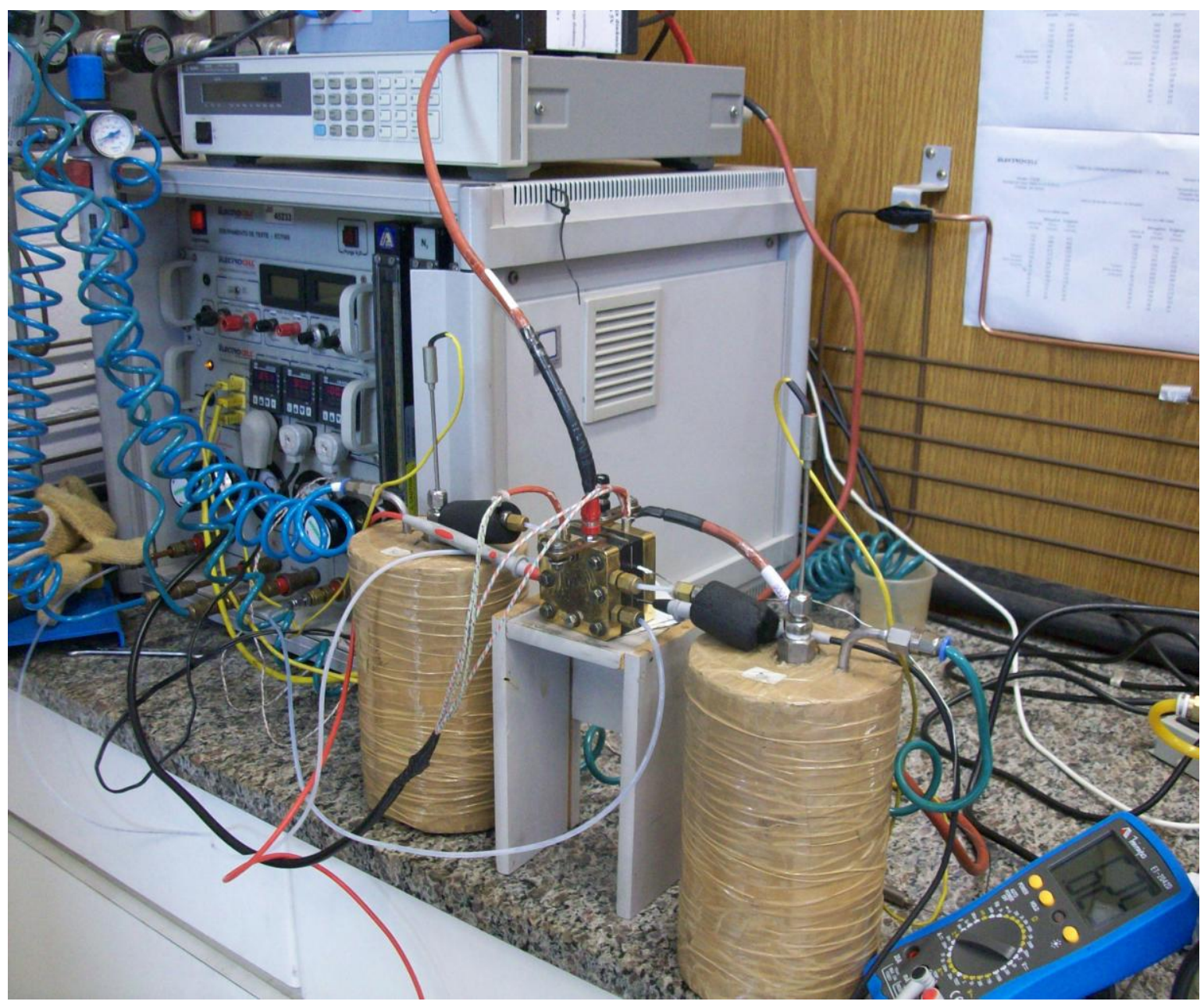

FIGURA 23. Sistema de operação da célula a combustível de baixa temperatura (PEMFC). 


\section{RESULTADOS E DISCUSSÕES}

\subsection{Eletrocatalisadores Pt:( $\left(\mathrm{Ce}_{0,9} \mathrm{Y}_{0,1} \mathrm{O}_{2}\right)+\mathrm{Pt} / \mathrm{C}$ Etek e Pt:($\left(\mathrm{Ce}_{0,9} \mathrm{Ru}_{0,1} \mathrm{O}_{2}+\mathrm{RuO}_{2}\right)+\mathrm{Pt} / \mathrm{C}$ Etek}

\subsubsection{Caracterização de eletrocatalisadores $\mathrm{Pt}:\left(\mathrm{Ce}_{0,9} \mathrm{Y}_{0,1} \mathrm{O}_{2}\right)+\mathrm{Pt} / \mathrm{C}$ Etek e $\mathrm{Pt}:\left(\mathrm{Ce}_{0,9} \mathrm{Ru}_{0,1} \mathrm{O}_{2}+\mathrm{RuO}_{2}\right)+\mathrm{Pt} / \mathrm{C}$ Etek}

$\mathrm{Na}$ Figura 24 são apresentados os difratogramas de raios $\mathrm{X}$ para o eletrocatalisador de Pt/C Etek e da mistura obtida através da ancoragem de $2 \%$ em massa de Pt em $\mathrm{Ce}_{0,9} \mathrm{Y}_{0,1} \mathrm{O}_{2}$ e $\mathrm{Ce}_{0,9} \mathrm{Ru}_{0,1} \mathrm{O}_{2}+\mathrm{RuO}_{2}$. Os difratogramas de raios $\mathrm{X}$ para os eletrocatalisadores preparados neste trabalho mostraram os picos característicos da $\mathrm{CeO}_{2}$ em valores aproximados de $2 \Theta=28,6^{\circ}, 33,1^{\circ}, 47,5^{\circ} \mathrm{e}$ $56,3^{\circ}$ que estão associados aos planos (111), (200), (220) e (311) respectivamente [49]. Os picos característicos da Pt não foram evidenciados na análise, provavelmente por causa de sua baixa porcentagem em massa na mistura. A reflexão do plano (111) da $\mathrm{CeO}_{2}$ foi utilizada para calcular o tamanho médio de cristalito de Céria (já que há pouca Pt na mistura) através da equação de Scherrer [48] para ambas misturas preparadas, sendo que para a mistura Pt: $\left(\mathrm{Ce}_{0,9} \mathrm{Y}_{0,1} \mathrm{O}_{2}\right)$ o valor encontrado foi de aproximadamente $8 \mathrm{~nm}$ e para a mistura Pt: $\left(\mathrm{Ce}_{0,9} \mathrm{Ru}_{0,1} \mathrm{O}_{2}+\mathrm{RuO}_{2}\right)$ o valor encontrado foi de aproximadamente $6 \mathrm{~nm}$.

Para o catalisador comercial Pt/C Etek foi encontrado um pico em $2 \Theta=25^{\circ}$ que está associado ao carbono e outros quatros picos associados a estrutura cúbica de face centrada da platina. 


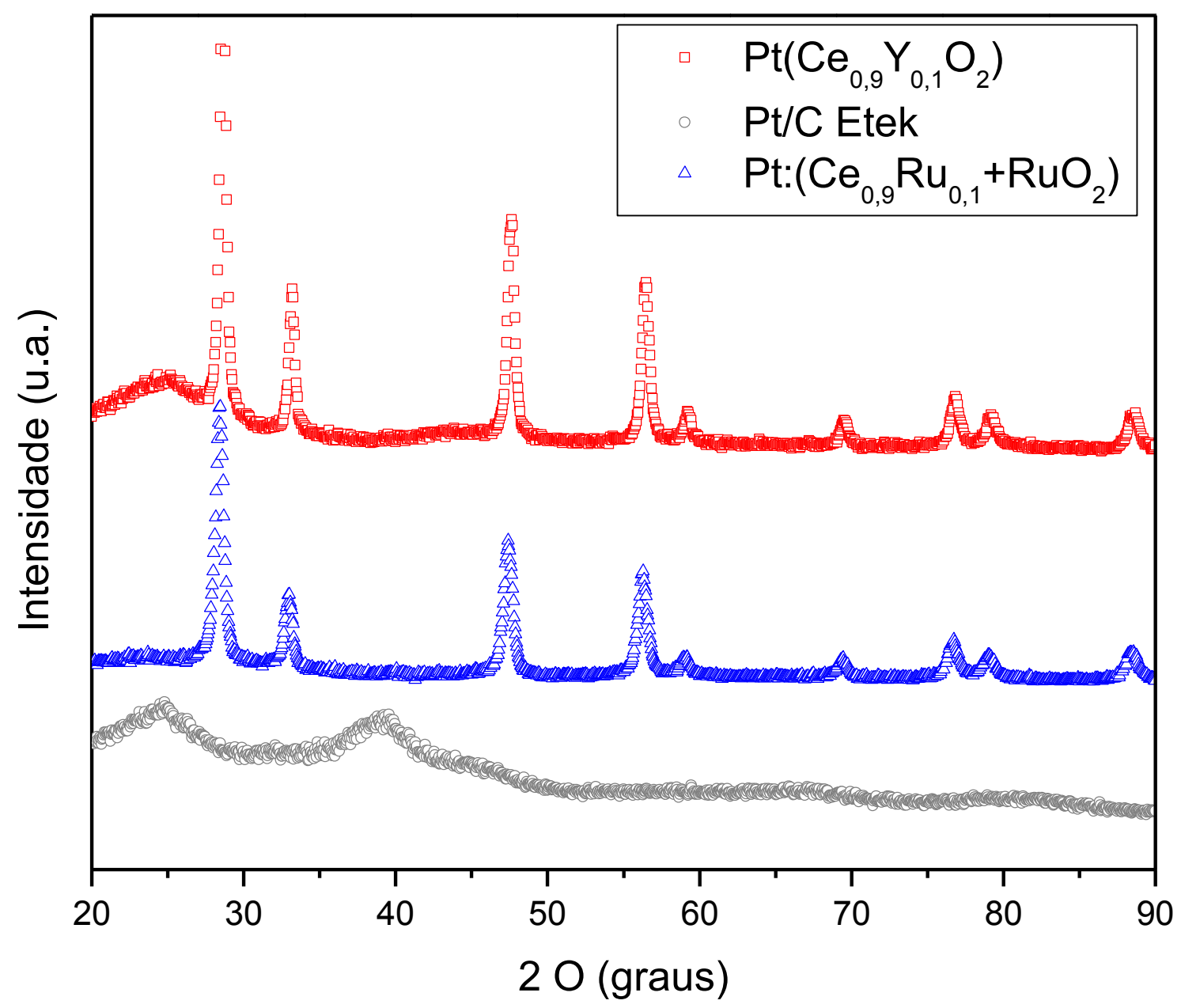

FIGURA 24. Difratograma de raio $X$ de $\mathrm{Pt}:\left(\mathrm{Ce}_{0,9} \mathrm{Y}_{0,1} \mathrm{O}_{2}\right)$ e $\mathrm{Pt}:\left(\mathrm{Ce}_{0,9} \mathrm{Ru}_{0,1} \mathrm{O}_{2}+\mathrm{RuO} \mathrm{O}_{2}\right)$ e $\mathrm{Pt} / \mathrm{C}$ Etek.

As microscopias de transmissão e histogramas dos eletrocatalisadores Pt: $\left(\mathrm{Ce}_{0,9} \mathrm{Y}_{0,1} \mathrm{O}_{2}\right)$ e Pt: $\left(\mathrm{Ce}_{0,9} \mathrm{Ru}_{0,1} \mathrm{O}_{2}+\mathrm{RuO}_{2}\right)$ são apresentadas nas Figuras 25 e 26 , respectivamente. A análise de MET mostraram uma aglomeração das partículas, sendo estas, em ambos os casos, de dimensões da ordem de $10 \mathrm{~nm}$.

Para a amostra de Pt: $\left(\mathrm{Ce}_{0,9} \mathrm{Y}_{0,1} \mathrm{O}_{2}\right)$ foi possível identificar alguns compostos, e através dessa identificação, estimou-se o tamanho da Platina ancorada na céria dopada, que foi de aproximadamente $7 \mathrm{~nm}$, sendo este valor estimado utilizando a amostragem das 3 partículas de platina identificadas na Figura 23. 


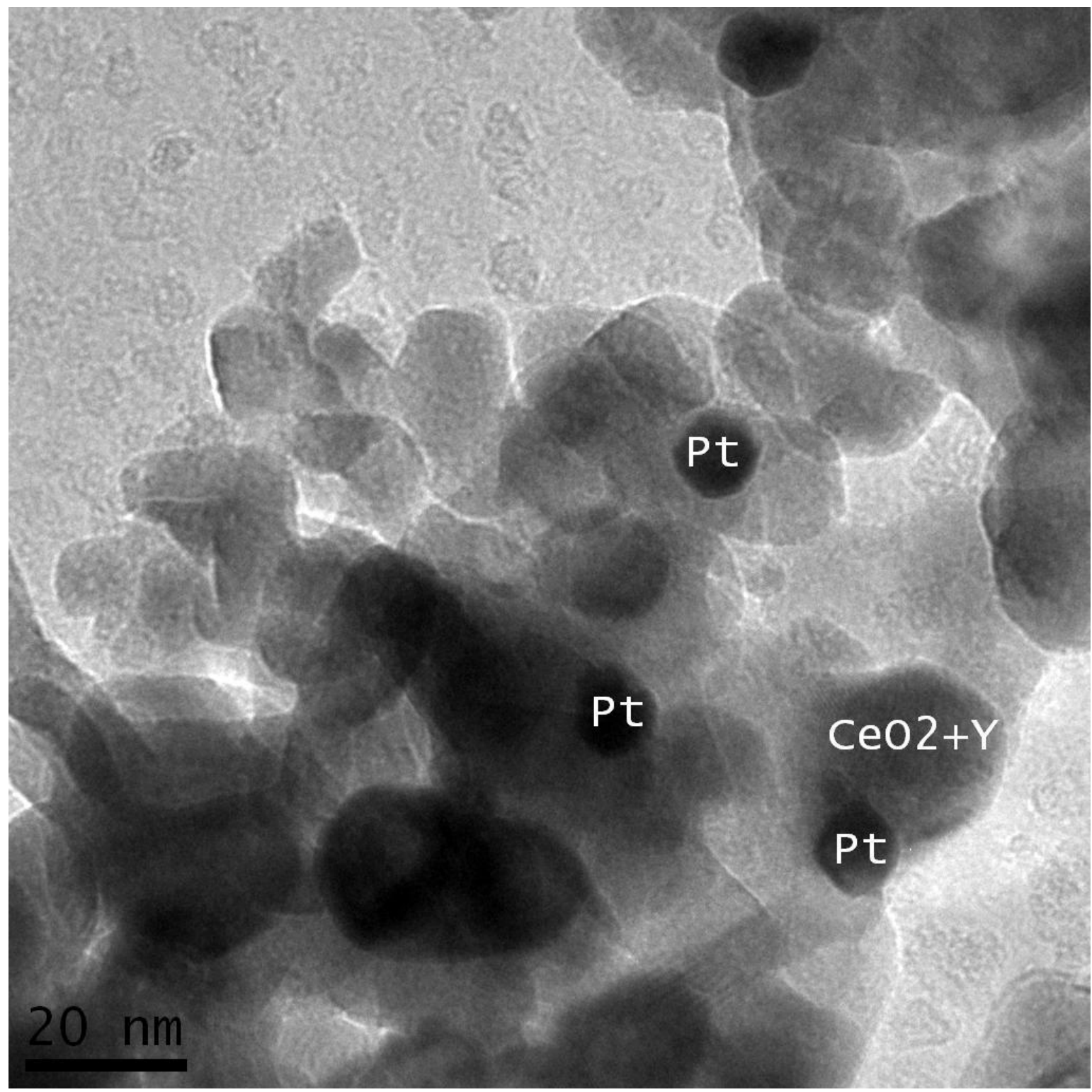

FIGURA 25 - Microscopia de transmissão da mistura obtida através da ancoragem de $2 \%$ em massa de platina em $\mathrm{Ce}_{0,9} \mathrm{Y}_{0,1} \mathrm{O}_{2}$.

No caso da micrografia de transmissão da amostra de $\mathrm{Pt}: \mathrm{Ce}_{0,9} \mathrm{Ru}_{0,1} \mathrm{O}_{2}$ $+\mathrm{RuO}_{2}$ (Figura 26), não foi possível identificar os compostos presentes, sendo assim não foi possível estimar o tamanho médio das partículas. 


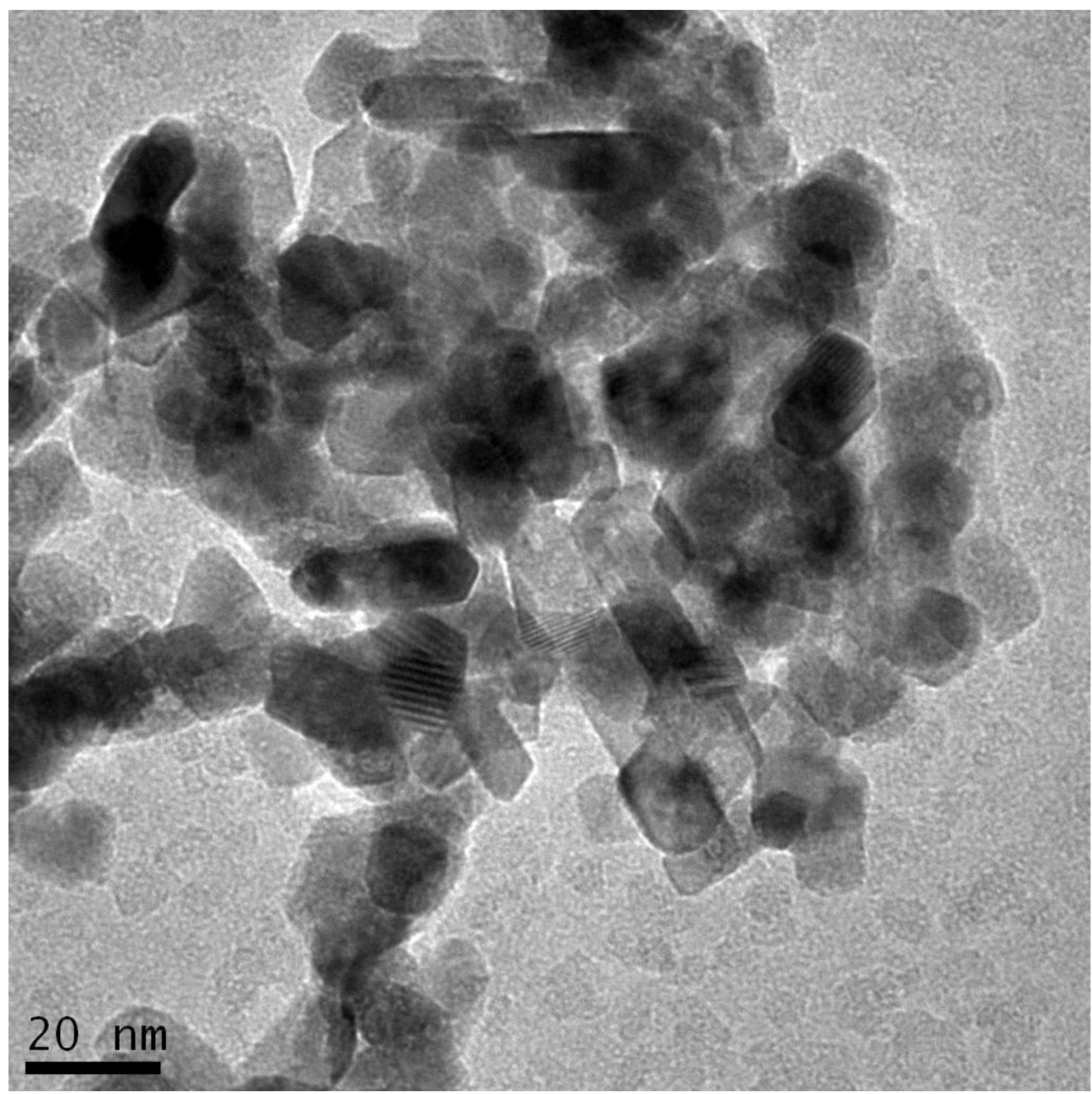

FIGURA 26 - Microscopia de transmissão da mistura obtida através da ancoragem de $2 \%$ em massa de platina em $\mathrm{Ce}_{0,9} \mathrm{Ru}_{0,1} \mathrm{O}_{2}+\mathrm{RuO}_{2}$.

Para uma melhor caracterização dos materiais preparados neste trabalho foram realizados estudos eletroquímicos para a oxidação do monóxido de carbono. Nestes estudos utilizou-se a técnica de voltametria cíclica para obter o perfil voltamétrico para os diferentes eletrocatalisadores preparados. Por intermédio da técnica de voltametria cíclica também é possível observar os processos de oxidação e redução que ocorrem na superfície dos eletrocatalisadores preparados.

Nos voltamogramas na ausência de CO geralmente é possível observar a formação de óxidos durante a varredura anódica (varredura positiva), 
enquanto que na varredura catódica (varredura negativa) podemos observar os processos de redução de óxidos formados durante a varredura anódica, consequentemente pode-se avaliar a reversibilidade dos processos estudados.

\subsubsection{Avaliação eletroquímica da reação de oxidação de CO}

\subsubsection{Stripping de CO}

Na Figura 27, são apresentados os voltamogramas de stripping de $\mathrm{CO}$ para os eletrocatalisadores de Pt/C Etek, Pt: $\left(\mathrm{Ce}_{0,9} \mathrm{Y}_{0,1} \mathrm{O}_{2}\right)+\mathrm{Pt} / \mathrm{C}$ Etek e $\mathrm{Pt}:\left(\mathrm{Ce}_{0,9} \mathrm{Ru}_{0,1} \mathrm{O}_{2}+\mathrm{RuO}_{2}\right)+\mathrm{Pt} / \mathrm{C}$ Etek obtidos no intervalo de 0,1 a $0,9 \mathrm{~V}$ vs $\mathrm{ERH}$, com velocidade de varredura de $20 \mathrm{mV} . \mathrm{s}^{-1}$. As curvas em círculos vermelhos e quadrados pretos correspondem ao voltamograma cíclico na ausência e presença de $\mathrm{CO}$, respectivamente. 


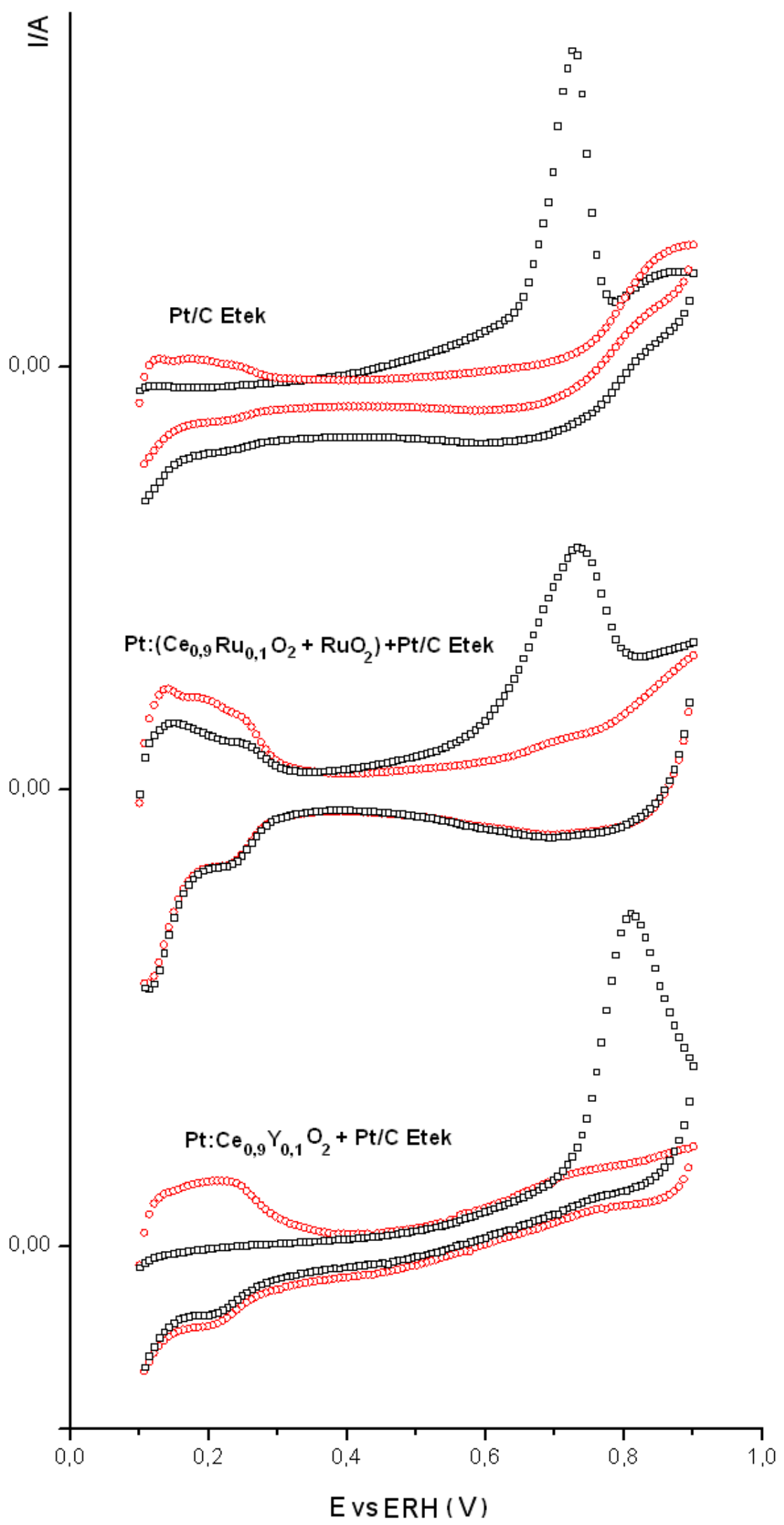

FIGURA 27. Voltomogramas de Stripping de CO para os eletrocatalisadores de Pt: $\mathrm{Ce}_{0,9} \mathrm{Y}_{0,1} \mathrm{O}_{2}+\mathrm{Pt} / \mathrm{C}$ Etek ou Pt:Ce $e_{0,9} \mathrm{Ru}_{0,1} \mathrm{O}_{2}+\mathrm{RuO}_{2}+\mathrm{Pt} / \mathrm{C}$ Etek em uma célula a combustível tipo PEMFC com $\mathrm{v}=20 \mathrm{mVs}^{-1}$ a $25^{\circ} \mathrm{C}$. 
Na curva de stripping de CO para Pt/C Etek foi possível constatar que o potencial inicial de oxidação do $\mathrm{CO}$ para a $\mathrm{Pt} / \mathrm{C}$ Etek é de $0,65 \mathrm{~V}$ e que o pico máximo de oxidação ocorreu em $0,73 \mathrm{~V}$ aproximadamente, de acordo com os valores encontrados em literatura [43] e está associado à oxidação de uma monocamada de $\mathrm{CO}$ a $\mathrm{CO}_{2}$ na superfície do eletrocatalisador.

O eletrocatalisador preparado pela da ancoragem de $2 \%$ em massa de platina no suporte da céria dopada com rutênio e dióxido de rutênio e posterior adição de Pt/C Etek apresentou um pico de oxidação em 0,73 V, assim como o encontrado com a Pt/C Etek, porém, apresentou um potencial inicial de oxidação em aproximadamente 0,60 V. Este comportamento mostrou o efeito benéfico da adição de céria dopada com rutênio ao catalisador. Este efeito benéfico poderia estar associada a presença de espécies oxigenadas neste material, as quais poderiam auxiliar na oxidação do $\mathrm{CO}$ a $\mathrm{CO}_{2}$. Já o eletrocatalisador baseado em céria dopada com ítria, preparado pelo mesmo método anterior apresentou potencial inicial de oxidação em torno de $0,66 \mathrm{~V}$ e pico de oxidação em $0,73 \mathrm{~V}$, também atestando um efeito benéfico da adição de céria dopada com itria no catalisador em comparação com Pt/C Etek, consequentemente, a mesma discussão utilizada para a céria dopada com rutênio poderia ser utilizada.

\subsubsection{Curva de polarização}

$\mathrm{Na}$ Figura 28 são apresentadas as curvas de polarização de $\mathrm{H}_{2}$ puro e $\mathrm{H}_{2} / \mathrm{CO} 100 \mathrm{ppm}$ dos eletrocatalisadores de Pt/C Etek, Pt: $\left(\mathrm{Ce}_{0,9} \mathrm{Y}_{0,1} \mathrm{O}_{2}\right)+\mathrm{Pt}$ Etek e Pt/C Etek e Pt: $\left(\mathrm{Ce}_{0,9} \mathrm{Ru}_{0,1} \mathrm{O}_{2}+\mathrm{RuO}_{2}\right)+\mathrm{Pt}$ Etek. 

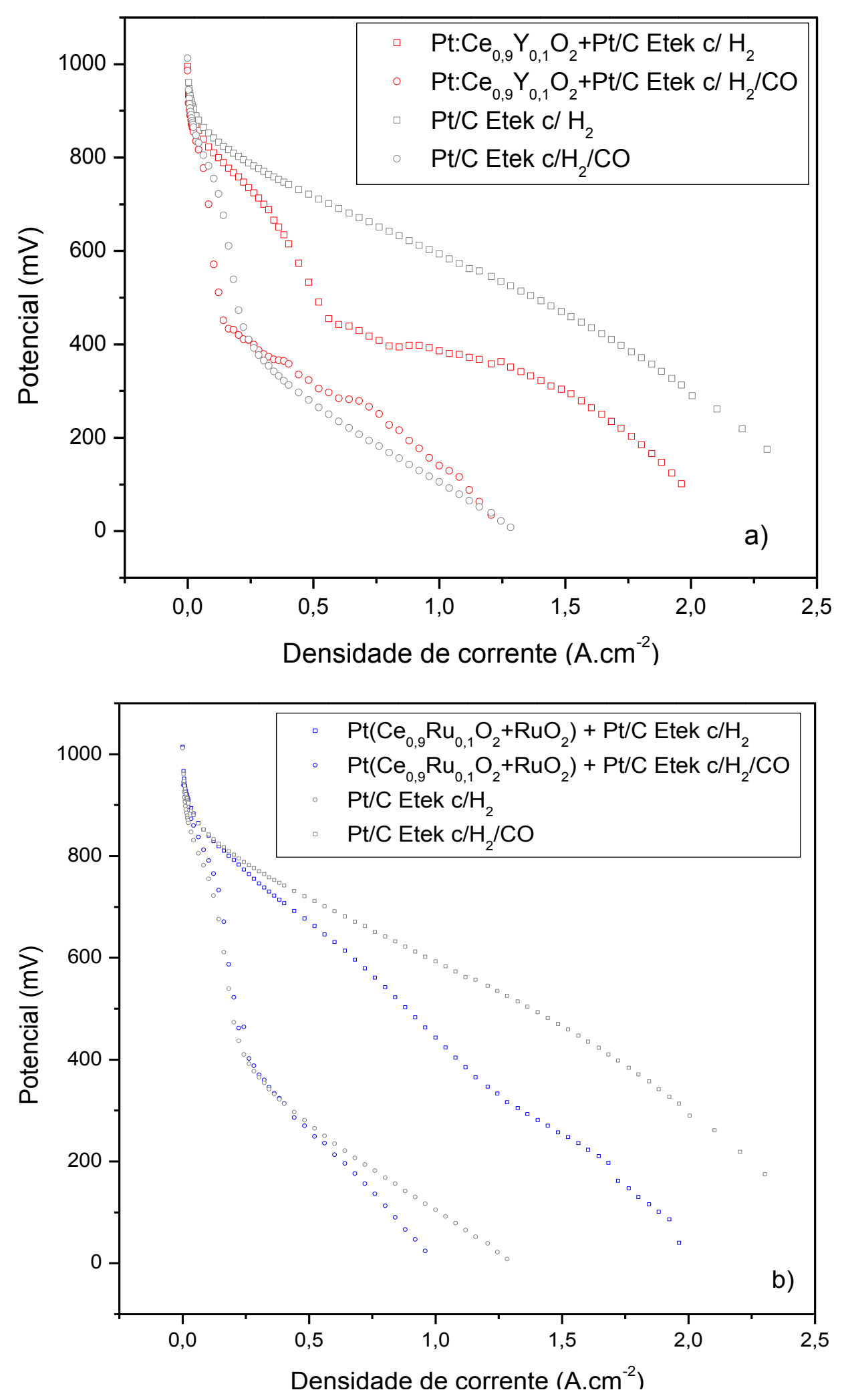

FIGURA 28 - Curvas de polarização de $\mathrm{H}_{2}$ puro e $\mathrm{H}_{2} / \mathrm{CO} 100$ ppm dos eletrocatalisadores: a) Pt/C Etek e Pt: $\left(\mathrm{Ce}_{0,9} \mathrm{Y}_{0,1} \mathrm{O}_{2}\right)+\mathrm{Pt}$ E-tek, b) Pt/C Etek e Pt: $\left(\mathrm{Ce}_{0,9} \mathrm{Ru}_{0,1} \mathrm{O}_{2}+\mathrm{RuO}_{2}\right)+\mathrm{Pt}$ E-tek. Cátodo e ânodo com carga de 0,4 mg Pt.cm ${ }^{-2}$. 
$\mathrm{Na}$ Figura 28 são apresentadas curvas de polarização para os eletrocatalisadores Pt: $\left(\mathrm{Ce}_{0,9} \mathrm{Y}_{0,1} \mathrm{O}_{2}\right)+\mathrm{Pt} / \mathrm{C}$ Etek (a) e Pt: $\left(\mathrm{Ce}_{0,9} \mathrm{Ru}_{0,1} \mathrm{O}_{2}+\mathrm{RuO}_{2}\right)+$ $\mathrm{Pt} / / \mathrm{C}$ Etek (b) comparados com $\mathrm{Pt} / \mathrm{C}$ Etek na presença de $\mathrm{H}_{2}$ puro e em uma mistura de $\mathrm{H}_{2} / \mathrm{CO} 100 \mathrm{ppm}$ com temperatura de operação de célula a $85^{\circ} \mathrm{C}$ e pressão de 2 atm.

Em ambos eletrocatalisadores testados evidenciou-se um baixo desempenho, para todos potenciais, quando comparados com o eletrocatalisador comercial Pt/C Etek. Este baixo desempenho pode ser justificado pelo método em que os eletrocatalisadores testados foram preparados, já que ancorou-se apenas $2 \%$ de Pt na superfície da céria, não garantindo uma grande quantidade de Pt próxima a céria, dificultando a transferência de espécies oxigenadas para superfície da platina contaminada com $\mathrm{CO}$, ou por outro lado, há pouco sítios de platina para adsorção de $\mathrm{CO}$ e, consequentemente, este comportamento poderia resultar na reduzida atividade observada. Um outro problema poderia estar associado a uma maior resistividade do eletrodo de difusão gasosa decorrente da presença da céria. Este resultado indicou que precisariam ser introduzidas mudanças nas sínteses e preparação destes eletrocatalisadores. As mudanças propostas serão apresentadas no próximo item.

\subsection{Eletrocatalisadores de $\mathrm{Pt}: \mathrm{Ce}_{0,9} \mathrm{Y}_{0,1} \mathrm{O}_{2} / \mathrm{C}$ e Pt: $\left(\mathrm{Ce}_{0,9} \mathrm{Ru}_{0,1} \mathrm{O}_{2}+\mathrm{RuO} \mathrm{O}_{2}\right) / \mathrm{C}$}

\subsubsection{Caracterização de eletrocatalisadores $\mathrm{Pt}: \mathrm{Ce}_{0,9} \mathrm{Y}_{0,1} \mathrm{O}_{2} / \mathrm{C}$ e Pt: $\left(\mathrm{Ce}_{0,9} \mathrm{Ru}_{0,1} \mathrm{O}_{2}+\mathrm{RuO}_{2}\right) / \mathrm{C}$}

$\mathrm{Na}$ Figura 29 são apresentados os difratogramas de raios $\mathrm{X}$ dos eletrocatalisadores de $\mathrm{Pt}: \mathrm{Ce}_{0,9} \mathrm{Y}_{0,1} \mathrm{O}_{2} / \mathrm{C}$ e $\mathrm{Pt}:\left(\mathrm{Ce}_{0,9} \mathrm{Ru}_{0,1} \mathrm{O}_{2}+\mathrm{RuO} \mathrm{O}_{2}\right) / \mathrm{C}$, obtidos através da ancoragem de $20 \%$ de platina através do método da redução por álcool e do eletrocatalisador Pt/C Etek. Nos três difratogramas, observa-se um pico largo em aproximadamente $2 \Theta=25^{\circ}$, que é associado ao suporte de carbono Vulcan XC72 utilizado para preparação deste eletrocatalisador. 


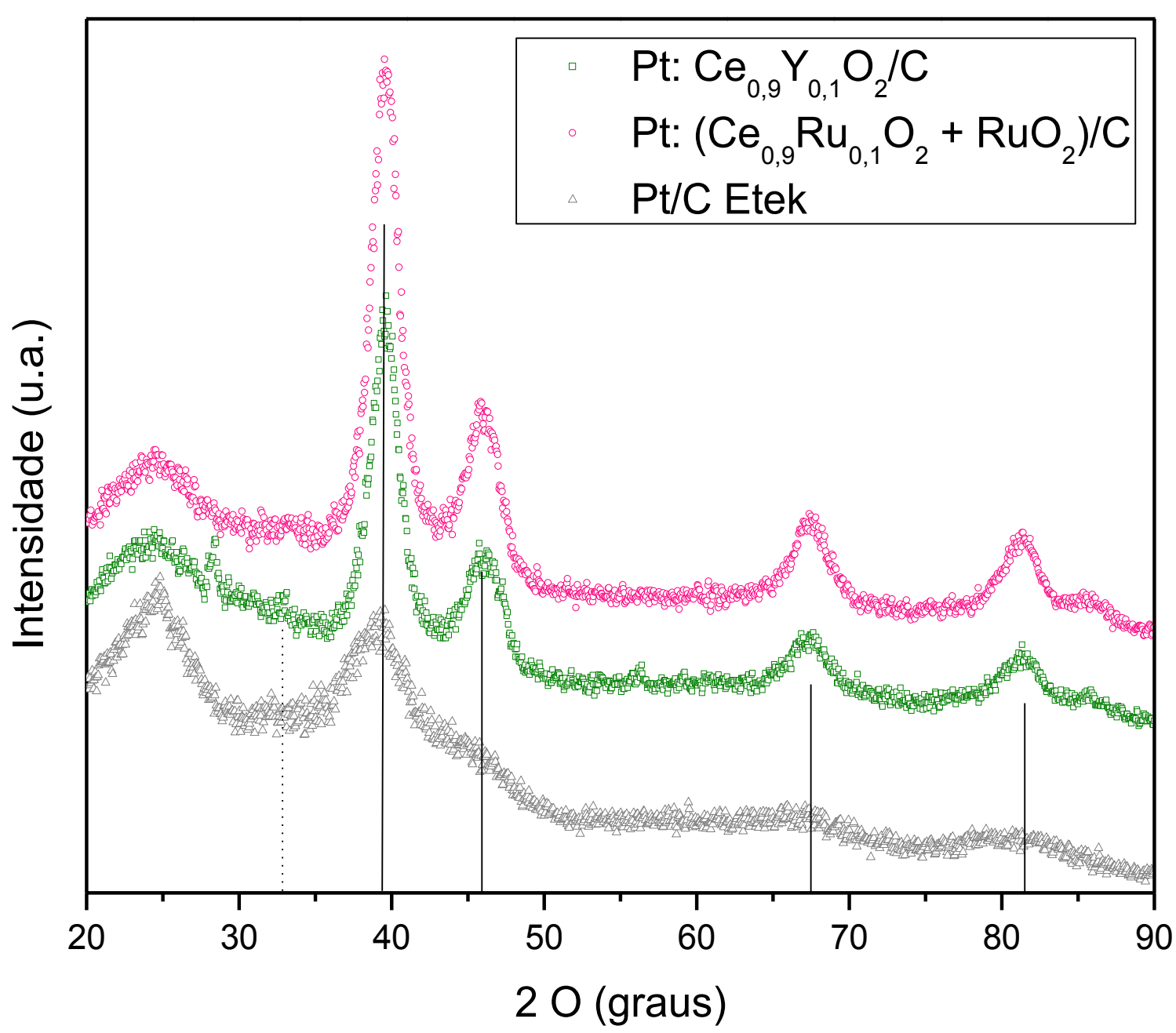

FIGURA 29. Difratograma de raio $X$ dos eletrocatalisadores $P t: \mathrm{Ce}_{0,9} \mathrm{Y}_{0,1} \mathrm{O}_{2} / \mathrm{C}$ e Pt:($\left(\mathrm{Ce}_{0,9} \mathrm{Ru}_{0,1} \mathrm{O}_{2}+\mathrm{RuO}_{2}\right) / \mathrm{C}$

Observou-se também nos difratogramas dos eletrocatalisadores de $\mathrm{Pt}\left(\mathrm{Ce}_{0,9} \mathrm{Ru}_{0,1} \mathrm{O}_{2}+\mathrm{RuO}_{2}\right) / \mathrm{C}$ e Pt:Ce $e_{0,9} \mathrm{Y}_{0,1} \mathrm{O}_{2} / \mathrm{C}$ um pequeno pico de difração no valor aproximado de $2 \theta=33^{\circ}$, referente ao plano (200) da $\mathrm{CeO}_{2}$ [49]. Picos nos valores aproximados de $2 \theta=39^{\circ}, 46^{\circ}, 67^{\circ}$ e $82^{\circ}$ estão associados aos planos (111), (200), (220) e (311), respectivamente, da estrutura cúbica de face centrada (CFC) de platina e suas ligas [43]. A reflexão do plano (111) da estrutura cristalina da $\mathrm{Pt}(\mathrm{CFC})$ foi utilizada para calcular o tamanho médio de cristalito através da equação de Scherrer [48], sendo o valor encontrado, para ambos

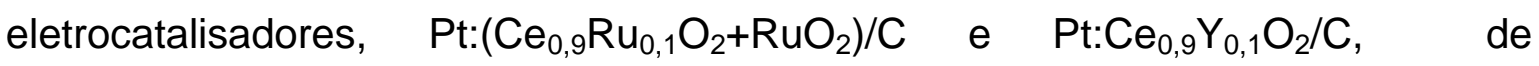
aproximadamente $3,5 \mathrm{~nm}$. 
As microscopias de transmissão e histogramas dos eletrocatalisadores $\mathrm{Pt}: \mathrm{Ce}_{0,9} \mathrm{Y}_{0,1} \mathrm{O}_{2} / \mathrm{C}$ e Pt: $\left(\mathrm{Ce}_{0,9} \mathrm{Ru}_{0,1} \mathrm{O}_{2}+\mathrm{RuO}_{2}\right) / \mathrm{C}$ são apresentadas nas Figuras $30 \mathrm{e}$ 31 , respectivamente. A análise de microscopia eletrônica de transmissão (MET) mostrou uma boa distribuição das nanopartículas sobre o suporte de carbono, não sendo evidenciados muitos aglomerados. No entanto é importante saliantar que a nova metodologia proposta mostrou-se mais efetiva do que a anterior apresentada se se considera o tamanho médio de partícula observado e a distribuição das nanoparticulas no suporte de carbono.

Através das microscopias foi possível calcular o tamanho médio de partícula. Para isso, uma amostragem de aproximadamente 150 partículas foi utilizada na quantificação. 

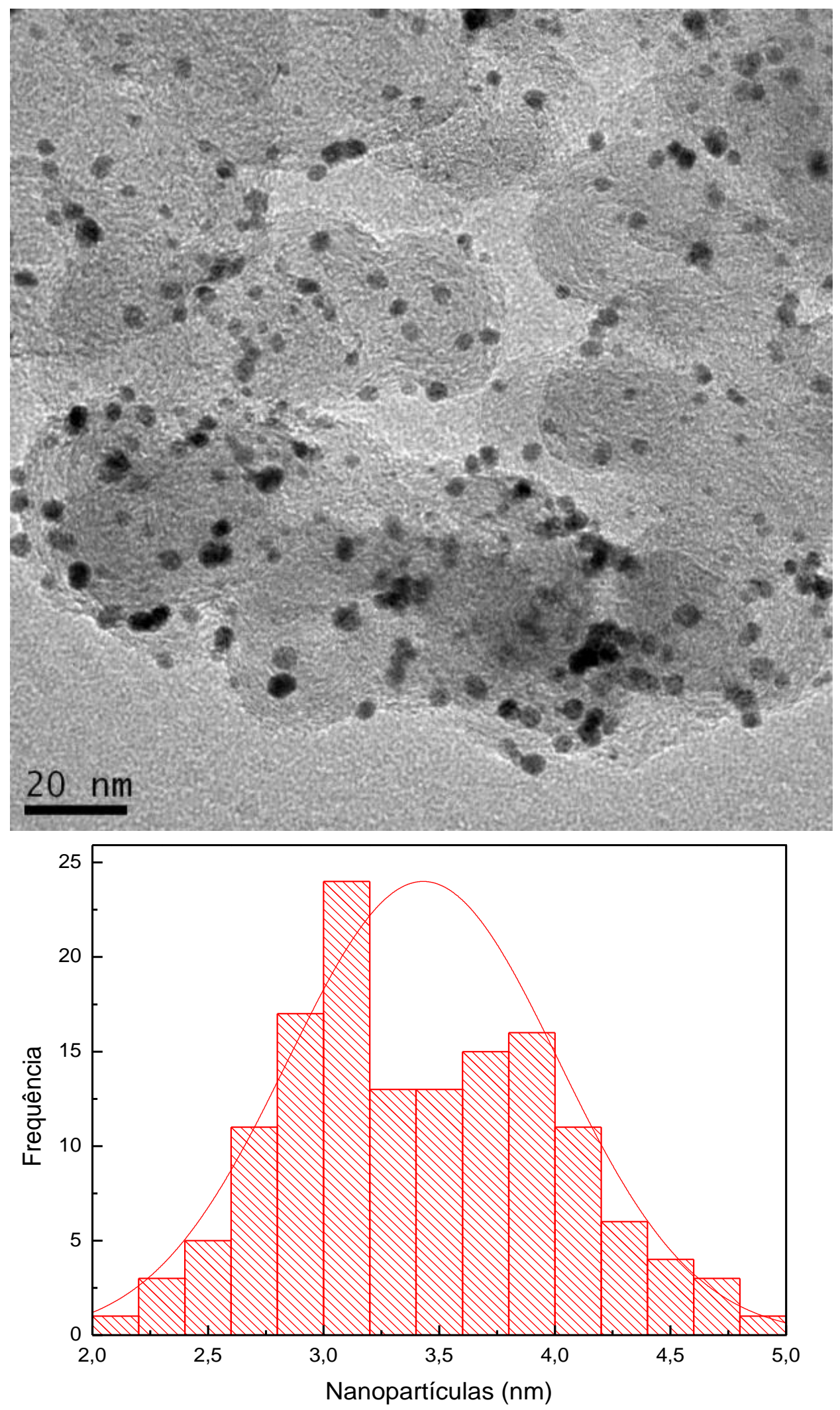

FIGURA 30 - Microscopia de transmissão do eletrocatalisador $\mathrm{Pt}: \mathrm{Ce}_{0,9} \mathrm{Y}_{0,1} \mathrm{O}_{2} / \mathrm{C}$ e seu respectivo histograma da distribuição dos tamanho de partícula. 
O tamanho médio de partícula calculada com base nas microscopias de MET para o eletrocatalisador Pt: $\mathrm{Ce}_{0,9} \mathrm{Y}_{0,1} \mathrm{O}_{2} / \mathrm{C}$ (Figura 30) foi de aproximadamente $3 \mathrm{~nm}$, o que condiz com os tamanhos médios de cristalitos estimados a partir dos dados de DRX, que foi menor do que o obtido com a MET, já que por DRX foi possível calcular apenas o tamanho dos cristalitos, que tendem a ser menores que o tamanho de partícula presente. 

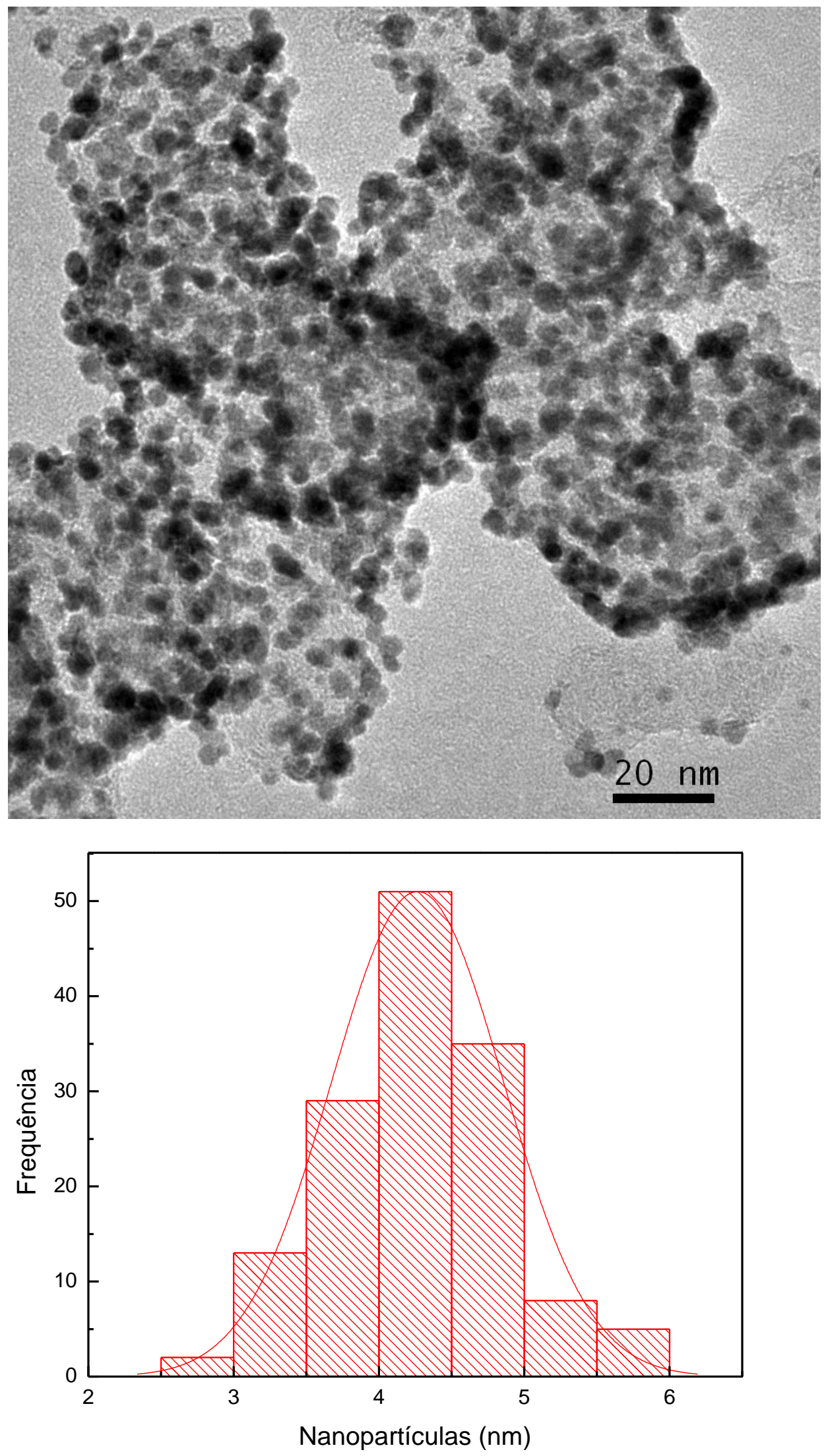

FIGURA 31 - Microscopia de transmissão do eletrocatalisador $\mathrm{Pt}:\left(\mathrm{Ce}_{0,9} \mathrm{Ru}_{0,1} \mathrm{O}_{2}+\mathrm{RuO}_{2}\right) / \mathrm{C}$ e seu respectivo histograma da distribuição dos tamanho de partícula. 
O tamanho médio de partícula calculada com base nas microscopias de transmissão (MET) para o eletrocatalisador Pt: $\left(\mathrm{Ce}_{0,9} \mathrm{Ru}_{0,1} \mathrm{O}_{2}+\mathrm{RuO}_{2}\right) / \mathrm{C}$ (Figura 31) foi de aproximadamente $4 \mathrm{~nm}$, o que condiz com os tamanhos médios de cristalitos estimados a partir dos dados de DRX, que foi de menor, pois trata-se do tamanho dos cristalitos. Os histogramas (apresentados ao lado das micrografias correspondentes) mostraram uma distribuição razoavelmente estreita de tamanhos de partículas atestando a efetividade do novo método proposto.

\subsubsection{Avaliação eletroquímica da reação de oxidação de CO}

\subsubsection{Stripping de CO}

Na Figura 32 são apresentados os voltamogramas cíclicos de stripping de CO para os eletrocatalisadores de Pt/C Etek, Pt: $\mathrm{Ce}_{0,9} \mathrm{Y}_{0,1} \mathrm{O}_{2} / \mathrm{C}$ e Pt: $\left(\mathrm{Ce}_{0,9} \mathrm{Ru}_{0,1} \mathrm{O}_{2}+\mathrm{RuO}_{2}\right) / \mathrm{C}$, obtidos no intervalo de 0,1 a $0,9 \mathrm{~V}$ vs $\mathrm{ERH}$, com velocidade de varredura de $20 \mathrm{mV} . \mathrm{s}^{-1}$. As curvas em círculos vermelhos e quadrados pretos correspondem ao voltamograma cíclico na ausência e presença de $\mathrm{CO}$, respectivamente.

As curvas de stripping de CO para os eletrocatalisadores preparados através da ancoragem de $20 \%$ em massa de platina sobre os suportes de céria dopada $\left(\mathrm{Ce}_{0,9} \mathrm{Y}_{0,1} \mathrm{O}_{2}\right.$ ou $\left.\mathrm{Ce}_{0,9} \mathrm{Ru}_{0,1} \mathrm{O}_{2}+\mathrm{RuO}_{2}\right)$ e carbono, apresentaram 2 picos de oxidação de CO. 


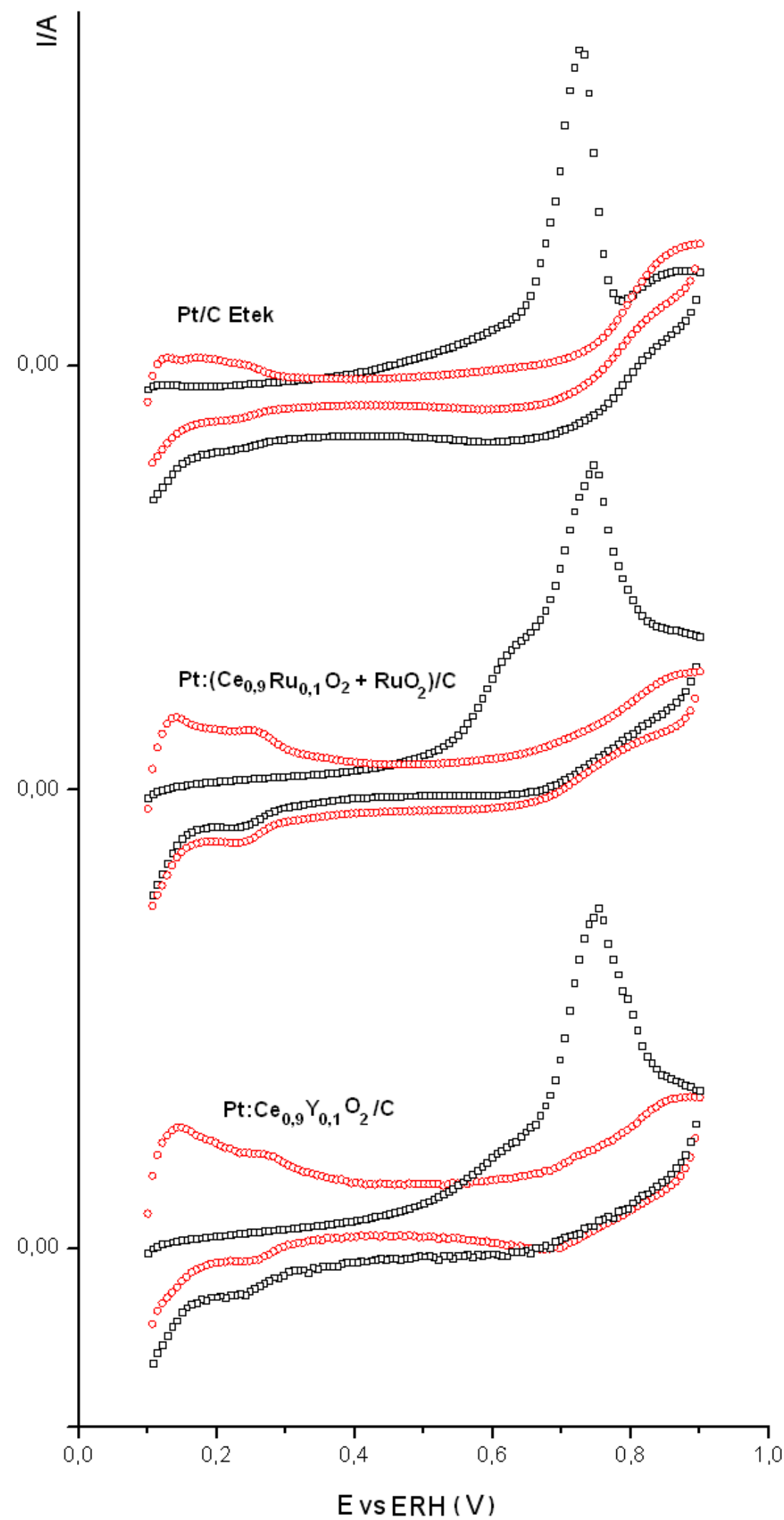

FIGURA 32. Voltomogramas Cíclicos de Stripping de $\mathrm{CO}$ para os eletrocatalisadores de Pt: $\mathrm{Ce}_{0,9} \mathrm{Y}_{0,1} \mathrm{O}_{2} / \mathrm{C}$ e Pt: $\left(\mathrm{Ce}_{0,9} \mathrm{Ru}_{0,1} \mathrm{O}_{2}+\mathrm{RuO}_{2}\right) / \mathrm{C}$ em uma célula a combustível tipo PEMFC com v $=20 \mathrm{mVs}^{-1}$ a $25^{\circ} \mathrm{C}$. 
Ambas formulações de eletrocatalisadores apresentaram potencial inicial de oxidação de $\mathrm{CO}$ em torno de $0,54 \mathrm{~V}$. O potencial de pico do primeiro processo de oxidação foi de aproximadamente $0,62 \mathrm{~V}$, sucedido por um segundo processo de oxidação no potencial de pico de aproximadamente $0,75 \mathrm{~V}$. A presença desses dois picos de oxidação nas curvas de stripping de $\mathrm{CO}$ dos eletrocatalisadores Pt: $\left(\mathrm{Ce}_{0,9} \mathrm{Ru}_{0,1} \mathrm{O}_{2}+\mathrm{RuO}_{2}\right) / \mathrm{C}$ e $\mathrm{Pt}: \mathrm{Ce}_{0,9} \mathrm{Y}_{0,1} \mathrm{O}_{2} / \mathrm{C}$ podem ser justificados pelos tipos de espécies adsorvidas. Através das curvas de stripping, pode-se dizer que há adsorção concomitante de espécies de $\mathrm{CO}_{\mathrm{B}}$ e $\mathrm{CO}_{\mathrm{L}}$, diferentemente da $\mathrm{Pt} / \mathrm{C}$ Etek, onde a adsorção predominante é de $\mathrm{CO}_{\mathrm{L}}$ [44]. Com base nos valores de potencial de pico, é possível afirmar que a presença de espécies oxigenadas da céria dopada auxiliam somente na oxidação de espécies mais fracamente adsorvidas $\left(\mathrm{CO}_{\mathrm{B}}\right)$, já que não foi observado deslocamento mais negativo do potencial de pico de oxidação do $\mathrm{CO}_{\mathrm{L}}$, comparando-se com a Pt/C Etek. Também podem-se justificar a presença desses dois picos de oxidação devido ao método utilizado na preparação estes eletrocatalisadores, já que reduziu-se $20 \%$ de Pt em céria dopada e carbono, aumentando as chances de ter elevada área superficial de Pt na superfície da céria.

\subsubsection{Curvas de polarização}

$\mathrm{Na}$ Figura 33 são apresentadas as curvas de polarização de eletrocatalisadores de Pt/C Etek, $\mathrm{Pt}: \mathrm{Ce}_{0,9} \mathrm{Y}_{0,1} \mathrm{O}_{2} / \mathrm{C}$ e Pt: $\left(\mathrm{Ce}_{0,9} \mathrm{Ru}_{0,1} \mathrm{O}_{2}+\mathrm{RuO}_{2}\right) / \mathrm{C}$ em célula a combustível unitária, alimentada com $\mathrm{H}_{2}$ puro e mistura $\mathrm{H}_{2} / \mathrm{CO} 100$ ppm, sendo a temperatura de operação da célula de $85^{\circ} \mathrm{C}$. 

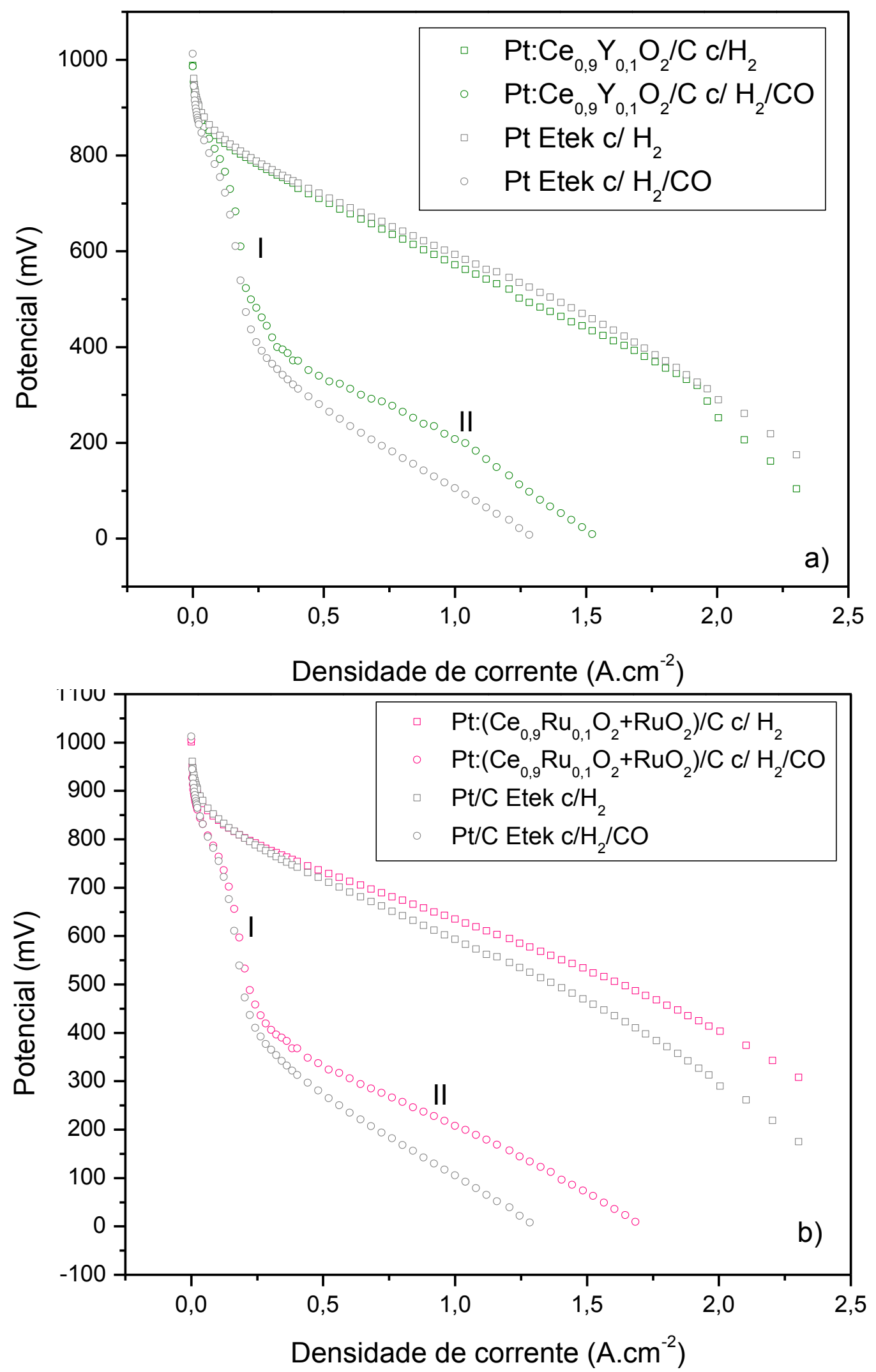

FIGURA 33 - Curvas de polarização de $\mathrm{H}_{2}$ puro e $\mathrm{H}_{2} / \mathrm{CO} 100$ ppm dos eletrocatalisadores: a) Pt/C Etek e Pt: $\mathrm{Ce}_{0,9} \mathrm{Y}_{0,1} \mathrm{O}_{2} / \mathrm{C}$, b) Pt/C Etek e Pt: $\left(\mathrm{Ce}_{0,9} \mathrm{Ru}_{0,1} \mathrm{O}_{2}+\mathrm{RuO}_{2}\right) / C$. Cátodo e ânodo com carga de $0,4 \mathrm{mg} \mathrm{Pt.cm}{ }^{-2}$. 
$\mathrm{Na}$ Figura 33 são apresentadas curvas de polarização para os eletrocatalisadores Pt: $\mathrm{Ce}_{0,9} \mathrm{Y}_{0,1} \mathrm{O}_{2} / \mathrm{C}$ (a) e $\mathrm{Pt}: \quad\left(\mathrm{Ce}_{0,9} \mathrm{Ru}_{0,1} \mathrm{O}_{2}+\mathrm{RuO}_{2}\right) / \mathrm{C} \quad$ (b) comparados com Pt/C Etek na presença de $\mathrm{H}_{2}$ puro e em uma mistura de $\mathrm{H}_{2} / \mathrm{CO}$ 100 ppm com temperatura de operação de célula de 85ㄷ e pressão de $2 \mathrm{~atm}$. Em ambos sistemas de eletrocatalisadores estudados, bem como no comercial $\mathrm{Pt} / \mathrm{C}$ Etek, observam-se dois patamares de oxidação, ou seja, duas etapas de oxidação do $\mathrm{CO}$. O patamar I refere-se à oxidação de espécies de $\mathrm{CO}$ fracamente adsorvidas, enquanto que o patamar II refere-se às espécies de $\mathrm{CO}$ mais fortemente adsorvidas. Para efeito comparativo, o sobrepotencial foi calculado por meio da diferença de potencial entre as curvas de polarização de $\mathrm{H}_{2}$ puro e da mistura de $\mathrm{H}_{2} / \mathrm{CO}$, na densidade de corrente de $1 \mathrm{~A} . \mathrm{cm}^{-2}$. Para o catalisador $\mathrm{Pt} / \mathrm{C}$ Etek observou-se um sobrepotencial de aproximadamente $486 \mathrm{mV}$, enquanto que o sistema $\mathrm{Pt}\left(\mathrm{Ce}_{0,9} \mathrm{Ru}_{0,1} \mathrm{O}_{2}+\mathrm{RuO}_{2}\right) / \mathrm{C}$ apresentou um sobrepotencial de aproximadamente $432 \mathrm{mV}$ e o sistema $\mathrm{Pt}: \mathrm{Ce}_{0,9} \mathrm{Y}_{0,1} \mathrm{O}_{2} / \mathrm{C}$ apresentou um sobrepotencial de aproximadamente $366 \mathrm{mV}$. Desse modo, ficou evidenciada a maior tolerância ao $\mathrm{CO}$ nos eletrocatalisadores $\mathrm{Pt}\left(\mathrm{Ce}_{0,9} \mathrm{Ru}_{0,1} \mathrm{O}_{2}+\mathrm{RuO}_{2}\right) / \mathrm{C}$ e $\mathrm{Pt}: \mathrm{Ce}_{0,9} \mathrm{Y}_{0,1} \mathrm{O}_{2} / \mathrm{C}$, pois estes apresentaram menor valor de sobrepotencial comparando-se com o catalisador Pt/C Etek. Assim, pode-se dizer que ambos eletrocatalisadores foram mais efetivos que o catalisador comercial $\mathrm{Pt} / \mathrm{C}$ Etek para oxidação do $\mathrm{CO}$, nestas condições estudadas. 


\section{CONCLUSÕES}

O método da redução do álcool foi efetivo para a preparação de catalisadores de platina com céria dopada com rutênio e platina com céria dopada com ítria. No entanto, os catalisadores foram mais efetivos que o eletrocatalisador de Pt/C E-tek quando foi empregado o segundo método proposto de preparação dos eletrocatalisadores.

Os resultados de difração de raios $\mathrm{X}$, considerando a segunda metodologia proposta, mostraram a presença de um pico largo em aproximadamente $2 \Theta=25^{\circ}$, que é associado ao suporte de carbono Vulcan XC72 utilizado para preparação deste eletrocatalisador, um pequeno pico de difração no valor aproximado de $2 \theta=33^{\circ}$, referente ao plano (200) da $\mathrm{CeO}_{2}$, e vários picos nos valores aproximados de $2 \theta=39^{\circ}, 46^{\circ}, 67^{\circ}$ e $82^{\circ}$, associados aos planos (111), (200), (220) e (311), respectivamente, da estrutura cúbica de face centrada (CFC) de platina e suas ligas.

A microscopia eletrônica de transmissão dos eletrocatalisadores preparados pela segunda metodologia mostraram tamanhos de partícula de 3 a 4 nm e uma boa distribuição da nanopartículas no suporte.

Estes resultados confirmaram que a metodologia proposta é bastante eficiente para a preparação de eletrocatalisadores a serem empregados nos estudos em célula a combustível do tipo PEM, visando tolerância ao CO.

O método de preparação de eletrocatalisadores baseados em céria, através da ancoragem de $2 \%$ em massa de platina na céria dopada e após adição de $\mathrm{Pt} / \mathrm{C}$ Etek para completar uma carga de $2 \mathrm{mgPt} . \mathrm{cm}^{-2}$ no eletrodo, não foi efetivo para oxidação do CO.

Estudos eletroquímicos evidenciaram que os sistemas de eletrocatalisadores $\mathrm{Pt}: \mathrm{Ce}_{0,9} \mathrm{Y}_{0,1} \mathrm{O}_{2} / \mathrm{C}$ e Pt: $\left(\mathrm{Ce}_{0,9} \mathrm{Ru}_{0,1} \mathrm{O}_{2}+\mathrm{RuO}_{2}\right) / \mathrm{C}$ apresentaram um melhor desempenho para oxidação de $\mathrm{CO}_{\text {ads }}$.

A presença da céria dopada, quando utilizada em eletrocatalisadores preparados pela ancoragem de $20 \%$ em massa de platina em $15 \%$ de céria dos 
$80 \%$ de suporte Carbon Black, favoreceu a oxidação de CO, nas condições adotadas, sendo este eletrocatalisador promissor para o uso em células a combustível tipo PEMFC, objetivo principal deste trabalho. 


\section{REFERÊNCIAS BIBLIOGRÁFICAS}

[1] AREAM. A Econômia do Hidrogénio. Agência Regional da Energia e Ambiente da Região Autônoma da Madeira.Disponível em: $<$ http://aream.pt/download/brochuras/Brochura_hidrogenio.pdf>. Acesso em: 11 mai. 2012.

[2] M. Linardi, Introdução à ciência e tecnologia de células a combustível, Ed ArtLiber, $1^{\text {a }}$ edição, 2010.

[3] Y.H. Kim; E.D. Park; H.C. Lee; D. Lee; K. H. Lee. Preferential CO oxidation over supported noble metal catalysts. Catalysis Today. 146, (2009) 253.

[4] D.A. Stevens; J.M. Rouleau; R.E. Mar; A. Bonakdarpour; R.T. Atanasoski, A.K. Schmoeckel; M.K. Debe; J.R. Dahn, Journal of the Electrochemical Society 154(2007) B566

[5] Z. Hou; H. Yi; H. Yu; Z. Lin; H. Zhang. CO tolerance electrocatalyst of PtRu$\mathrm{H}_{x} \mathrm{MeO}_{3} / \mathrm{C}(\mathrm{Me}=\mathrm{W}, \mathrm{Mo})$ made by composite support method. Jounal of Power Sources, 123, (2003) $116-125$.

[6] Energy/Renewable Energy. Nippon Oil to Sell Residential Fuel Cells in Japan. 2009. Disponível em: <http://treehgger.com/renewable-energy/nippon-oil-to-sellresidential-fuell-cells-in-japan.html>.Acesso em: 09.abr.2012.

[7] Types of fuel cells. Univerity os Cambridge. Disponível em: <WWW.doitpoms.ac.uk/ttplib/fuel-cells/types.php>.Acesso em: 11.mai.2012.

[8] Modeling Optimizes Fuel Cells. Galip Guvelioglu - Lehigh University, Bethlehem, PA. Disponível em: <http://comsol.com/stories/guvelioglu_fuel_cell/full/>.Acesso em: 10.abr.2012.

[9] E. A. Ticianelli; E. R. Gonzalez. Eletroquímica: Princípios a Aplicações - 2. ed. São Paulo: Editora da USP, 2005

[10] J. Nandenha. Desenvolvimento de novos sistemas de eletrocatalisadores nano-dispersos $20 \% \mathrm{Pt}-\left(2 \% \mathrm{Pt}_{-} \mathrm{Ce}_{0,9} \mathrm{~W}_{0,1} \mathrm{O}_{2}\right) / \mathrm{C}$ tolerantes ao monóxido de carbono (CO) para ânodos de PEMFC. Instituto de Pesquisas Energéticas e Nucleares. Universidade de São Paulo. Dissertação de Mestrado. São Paulo, 2012.

[11] M.M.V.M Souza; N.F.P. Ribeiro; M. Schmal. International Journal of Hydrogen Energy 32 (2007) 425.

[12] B.C.H. Steele; A. Heinzel, Materials for fuel-cell technologies. Nature, 414(2001) 345. 
[13] M. J. S. Farias; G. T. Filho; G. A. Camara. Eletrocatálise da oxidação de monóxido de carbono. Orbital. 1. (2009) 75-100.

[14] L. G. Pereira; E. A. Ticianelli. Avaliação do mecanismo de tolerância ao CO com catalisadores binários. In: XVI Simpósio Brasileiro de Eletroquímica e Eletroanalítica - SIBEE, 2007.

[15] I. E. Santiago; M. S. Batista; E. A. Ticianelli. Mechanism of CO Tolerance on Molybdenum-Based Electrocatalysts for PEMFC. Journal of electrochemical Society, 151,7, (2004) A944 - A949.

[16] I. E. Santiago; G. A. Camara; E. A. Ticianelli. CO tolerance on Pt-Mo/C Electrocatalysts prepared by the formic acid method. Electrochemica Acta, 48, (2003) $3257-3534$.

[17] B. Beden; C. Lamy; N.R. DE Tacconi; A.J. Arvia. The electrooxidation of CO-a test reaction in electrocatalysis, Electrochimica Acta, .35(4), (1990) 691.

[18] J. Divisek; H.F. Oetjen; V. Peinecke; V.M. Schmidt; U. Stimming. Components for PEM fuel cell systems using hydrogen and $\mathrm{CO}$ containing fuels. Electrochimica Acta .43(24) (1998) 3811.

[19] G.A. Camara; M.J. Giz; V.A. Paganin; E.A. Ticianelli. Correlation of electrochemical and physical properties of PtRu alloy electrocatalysts for PEMFC fuel cells, Journal of Electroanalytical Chemistry, 537,(2002) 21.

[20] H.A. Gasteiger; N.M. Markovic; P.N. Ross. $\mathrm{H}_{2}$ and $\mathrm{CO}$ electro-oxidation on Well-characterized Pt, Ru, and Pt-Ru. 1. Rotating Disk Electrode Studies of the pure gases including temperature effects. Journal of Physical Chemistry, 99 (1995) 8290.

[21] H. Inque; S.R. Brankovic; J.X. Wang; R.R. Adzic. Oxygen reduction on bare and $\mathrm{Pt}$ monolayer-modified $\mathrm{Ru}(0001), \mathrm{Ru}(1010)$ and $\mathrm{Ru}$ nanostrutured surfaces. Electrochimica Acta, 47 (2002) 3777.

[22] C.S.Chen; F.M.Pan; H.J.Yu. Electrocatalytic activity of Pt nanoparticles on a karst-like $\mathrm{Ni}$ thin film toward methanol oxidation in alkaline solutions. Applied Catalysis B. 104. 3-4. (2011) 382-389.

[23] J.G. Wang; B. Hammer. Theoretical study of $\mathrm{H}_{2} \mathrm{O}$ dissociation and $\mathrm{CO}$ oxidation on $\mathrm{Pt}_{2} \mathrm{Mo}$ (111), Journal of Catalysis, 243 (2006) 192.

[24] P. Atkins; J.Loretta. Princípios de Química. 5ªEd. 2011.

[25] D. Tibiletti; E. A. B. Graaf; S. P. The, G. Rothenberg; D. Farrusseng; C. Mirodatos. Selective CO oxidation in the presence of hydrogen: fast parallel screening and mechanistic studies on ceria-based catalysts. Journal of Catalysis, 225 (2004) 489-497 
[26] A. O. Neto. Estudos eletroquimicos sobre eletrocatalisadores a base de platina dispersos em carbono de alta area superficial. 2001. Tese (Doutorado) Universidade de São Paulo, São Paulo.

[27] H. Bönnemann; W. Brijoux; R. Brinkmann; E. Dinjus; T. Jouben; B. Korall; Angew. Chem., Int. Ed. 30 (1991) 1312.

[28] S. R. Brankovic; J. McBreen; R. R. Adazic; J. Electroanal. Chem. 99 (2001) 503.

[29] M. S. Nashner; A.I. Frenkel; D. L. Adler; J. R. Shapley; R. G. Nuzzo; J. Am. Chem. Soc. 119 (1997) 7760.

[30] N. Toshima; T. Yonezawa; New J. Chem. (1998) 1179

[31] E. V. Spinacé; A. O. Neto; E. G. Franco; M. Linardi; E. R. Gonzalez. Métodos de preparação de nanopartículas metálicas suportadas em carbono de alta area superficial, como eletrocatalisadores em células a combustível com membrana polimérica trocadora de protons. Quimica Nova, 27 (4) (2004) 648-654.

[32] A. O. Neto; L. A. Farias; R. R. Dias; M. Brandalise; M. Linardi, E. V. Spinacé. Enhanced electro-oxidation of ethanol using $\mathrm{Pt} / \mathrm{Sn} / \mathrm{CeO} 2-\mathrm{C}$ electrocatalyst prepared by na alcohol-reduction process. Electrochemistry Communications. 10 (2008) 1315-1317.

[33] Óxido de rutênio (IV). Wikipédia. Disponível em: <HTTP://pt.wikipedia.org/wiki/\%C3\%93xido_de_rut\%C3\%AAnio_(IV)>. Acesso em: 06.mar.2012.

[34] A. Neumann; D. Walter. The thermal transformation from lanthanum hydroxide to lanthanum hydroxide oxide. Thermochimica Acta 445 (2006)200-204

[35] A. Abrão. Química e Tecnologia das Terras Raras. Rio de Janeiro, Série tecnologia Mineral no66 CETEM/CNPq, 1994.

[36] G. Adachi, N. Imanaka, Chem. Rev., 98, (1998), 1479.

[37] Cerium(IV) oxide. Wikipedia. Disponível em: <http://en.wikipedia.org/wiki/Cerium(IV)_oxide>. Acesso em : 06.mar.2012.

[38] C. T. Campbell; C. H. Peden. Oxygen Vacancies and Catalysis on Ceria Surfaces. Science. 309 (2005) 713-714.

[39] F. Esch et al., Science. 309 (2005) 752..

[40] A. Migani; G. N. Vayssilov; S. T. Bromley; F. Illas; K. M. Neyman. Dramatic reduction of the oxygen vacancy formation energy in ceria particles: a possible key 
to their remarkable reactivity at the nanoscale. Journal of Materials Chemistry. 20 (2010) 10535-10546.

[41] Yttrium. Compounds of Yttrium. Disponível em: $<$ http://jpkc.whut.edu.cn/web18/main/wangluo/webelements/webelements/compou nds/text/y/o3y2-1314369.html>. Acesso em: 06.mar.2012.

[42] Electrolyte. University of Cambridge. Disponível em: $<$ http://doitpoms.ac.uk/tiplib/fuel-cells/sofc_electrolyte.php?printable=1>. Acesso em: 08.nov.2011.

[43] G.S. Li, R.L. Smith, H. Inomata, J. Am. Chem. Soc. 123 (2001) 11,09111,092 .

[44] G. Rothenberg, E.A. de Graaf, A. Bliek, Angew. Chem., Int. Ed. 42 (2003) 3066-3068.

[45] E. V. Spinacé; A. O. Neto; T. R. R. Vasconcellos; M. Linardi. Electro-oxidation of ethanol using PtRu/C electrocatalysts prepared by alcohol-reduction process. Journal of Power Sources, 137 (2004) 17.

[46] V. Radmilovic; H. A Gasteiger.; P. N. JR Ross. Structure and chemical composition of a supported Pt-Ru electrocatalyst for methanol oxidation. Journal of Catalysis, 154 (1995) 98.

[47] J. W. Guo; T. S. Zhao; J. Prabhuram; R. Chen; C. W. Wong. Development of $\mathrm{PtRu}-\mathrm{CeO}_{2} / \mathrm{C}$ anode electrocatalyst for direct methanol fuel cells. Journal of power sources. 156 (2006) 345-354.

[48] S.J. Lee; S. Mukerjee; E.A. Ticianelli; J. Mcbreen. Electrocatalysis of CO tolerance in hydrogen oxidation reaction in PEM fuel cells, Electrochimica Acta, 44 (1999) 3283.

[49] F.C. Simões; D.M. Andos; F. Vigier; J.-M. Léger; F. Hahn; C. Coutanceau; E.R. Gonzalez; G. T. Filho; A.R. Andrade; P. Olivi; K.B. Kokoh. Electroactivity of tin modified platinum electrodes for ethanol electroxidation, Journal of Power Sources. 167 (2007). 